$\Omega$ 于如干痘牛

要牛丰, 痖

沓移物學 7 毒

原宮入

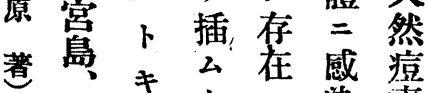

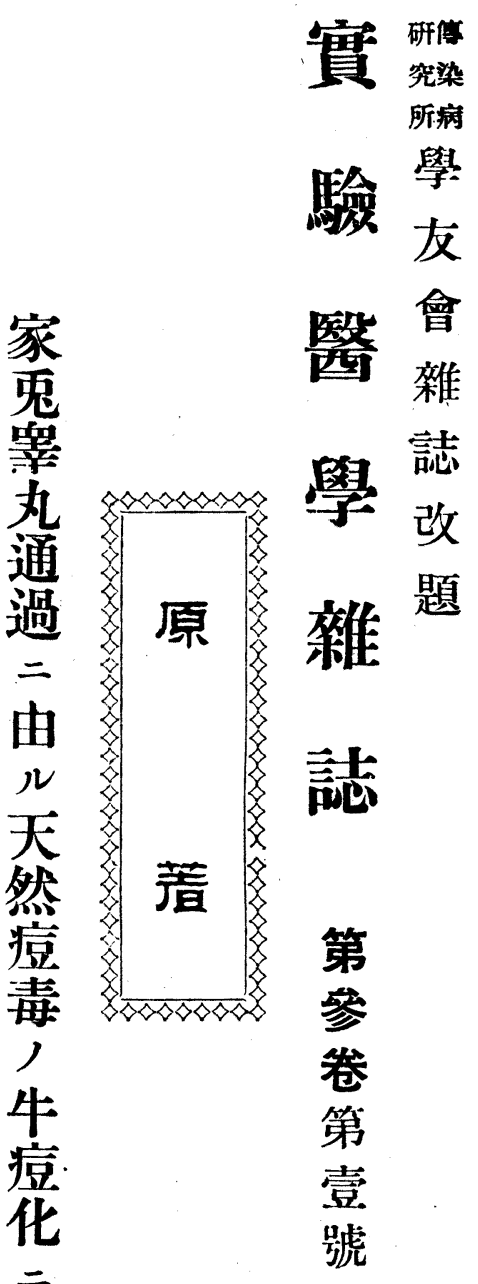

家总牛先所志牛

鬼空 八詳怘公體

䋨

望客言卜ル通

過气易七ス、過

言

由等此䕁然

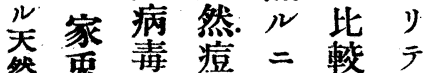

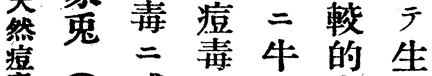

弯 感 $\exists \exists$ 容

告哭染先先易夕

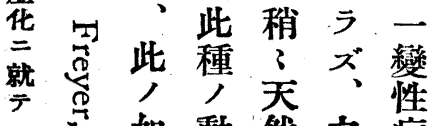
如 動 然之病

丰物痘之毒

总中心毒令 間接 = 日 y

等動種感倘卜 物 媣 我

及加. 现是

飞゙ シ之易等令

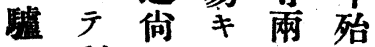

利示二病等

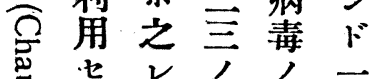

第 $三 \exists$ 動 同 $\overrightarrow{n^{2}}$

第吕 $\sim$ 、物源,

堂者一說信

壱者向り對

- 猿通今空所

虽過人多多

正七少儿

总恋牛疑

笠島城

就

井谷井

テ

種

久三佾

天

IE.

$\pi$

年

$\equiv$

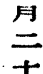

五

引

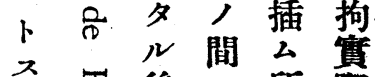

‥ 後 = 所 蔡

雄 郎 義 
其ク $尹$ 作ルト天 第于精用 九ンシセ卜り痘 こレクシ 於調通 又要, 厂查覽夕天經動 述委 $ル ル$ 過物 心員 $ル$ 後 + , 體 于會二三否如接 日 分威於 + 何種 P千染示站子陚

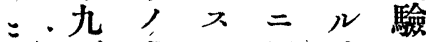
蒠成儿探時留 十否 $\exists$ 集期行 只宜

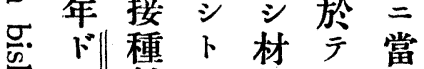

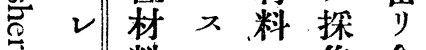
종 $ル$ 料集含然

§デ，成 天毒痘 $<$ ע\|l性等少的材材

二質, 可 $\neq$ 料料

開卜諸クカ,

空，點直疗選

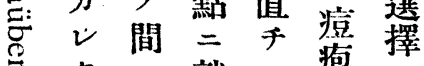

$\rightrightarrows$ タ 就二疮 $=$

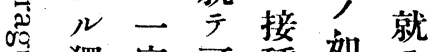

獨定可種如婎

逸, ナ七何

痘關りザナ其

苗係盛儿部接

製

造發討力分方

乺見論亏使法

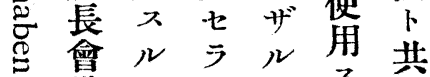

n. 議 $コ$ 力

亏

气報難り、名来

济然定患㧘

夕彼之時者實

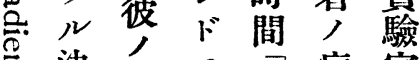

決獨芯病家

定逸從, 勢,

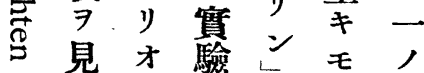

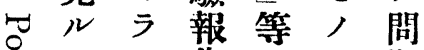

○モワ管 马夕題
ズレルメコロ毒驗痘功 八

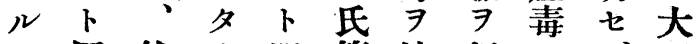
ヨ同然り明等培行人ザ正 以時 $ン$ : 左該此以り究 $ン$ 毒

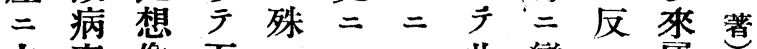
之毒像吾二ヨ、此變 シ庥 之八八人野り專際ズ猿々

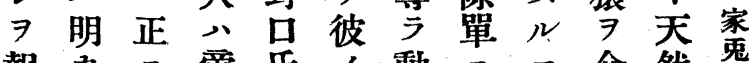

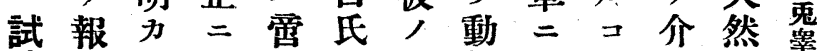
驗 告 $=$ 的 $=八 二$ 二物其 1 त痘势 三七牛中牛家三人皮 $\exists ル$ 毒週

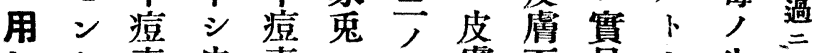
七下毒皮毒二亏膚面見 夕又二覤， 天元上。七痘

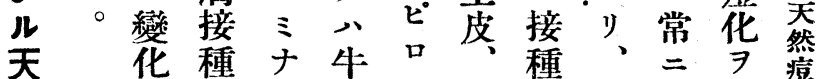
入八ラ痘分稀入次容試䊆

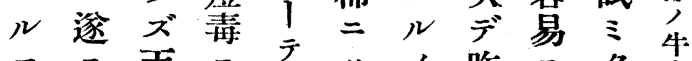
$=\equiv$ 天 $=$ 只, 昨 卜成然對三粘ミ年4 牛华 ヨ功痘 天於膜ナ, 體三就 見七毒ル方, ラ春二ガ熟 タザ二感ル上ズ天感之 リ、於受刃゙皮同然染 “三性，如組時痘 此 = $モ$ 織 實不亦皮牛 $习$ 睪東公接

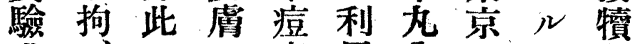
成, 二毒用內 績 天如於ガシ接流卜接 八然 $₹ r$ 家夕種行 7 種 學痘關 術毒係寻艿シモル爾

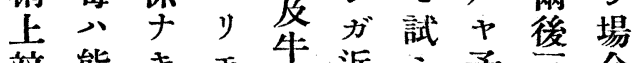
站能 $\neq ⿱ 一 土$ 生近予等合 $=夕=$ 寧人時夕等一第

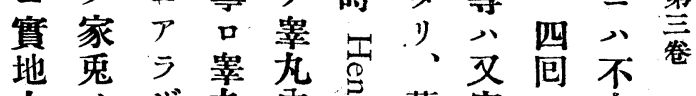
上至丸丙营蓋家幸

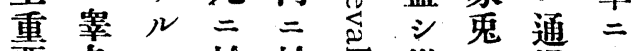

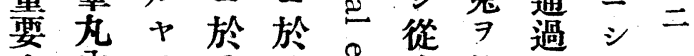

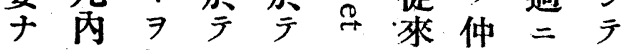
$ル=$ 想大 $匚 \delta$ 人 モ於像子能 痘者り多

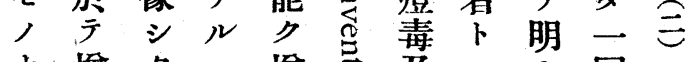
十增夕コ增き盘入力回 り殖ルト殖站ビルニ ダ 卜 $=$ = $=$ 牛, 信之由確ル野痘試然成 


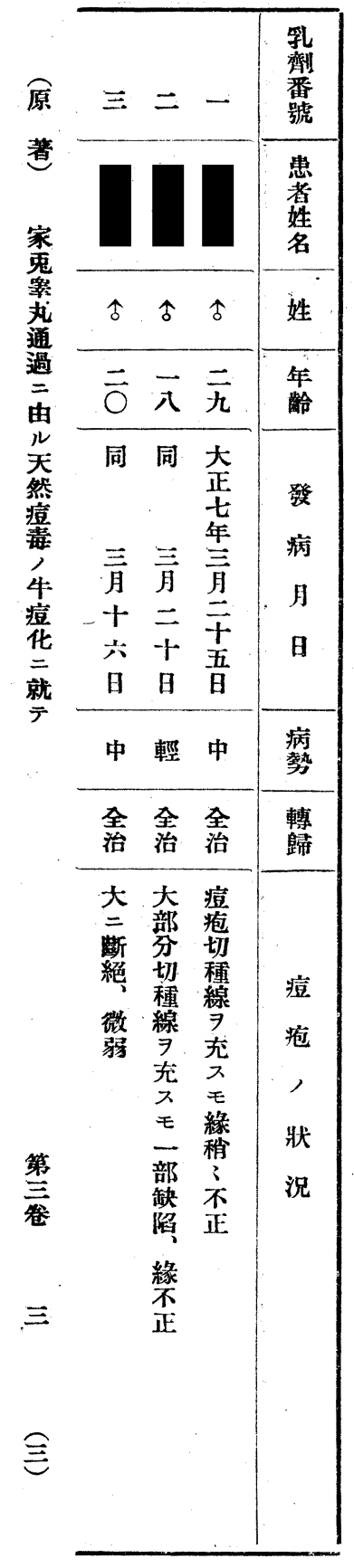

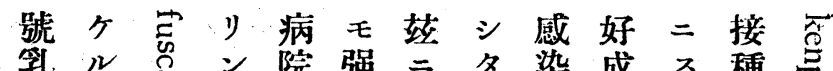

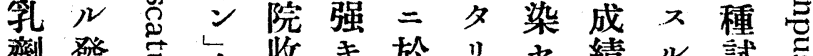

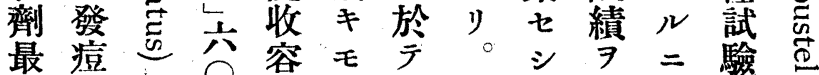

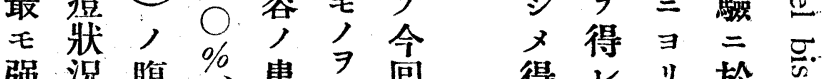
强況腹\%、患 $\exists$ 间 得 力八部石都選兔多ド猿至 于第二炭亲娟 ル备酸名示接 二, 表乳 ○名之種

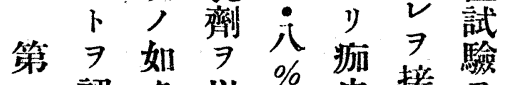
認”以 \%皮接然 - $z=\bar{z} \exists$ 種行

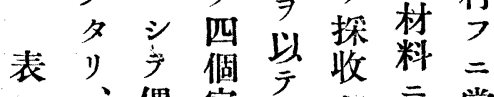
、偶笵方幥 体然然翌供罗

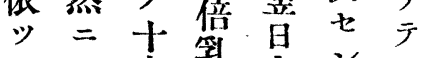

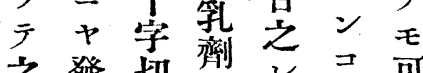
之發切诌之局 病種製 $\exists$ 品吕 习後切製減寻的

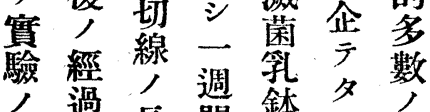
, 過長間等名,

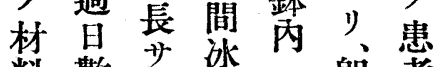
料數荷永二即著 二最何䡐平寻 供王々丙微大》

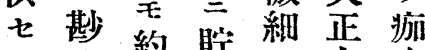

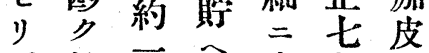
且一磨年夷 主夕碎四探

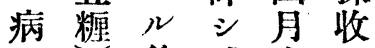
, 後減十 最 7 同菊分先 モ施月七日音 重 $三$ 二 赤痘山猿 y五苗醫三 佂製學對 患其一造士 者接培角; 二種, 混好. 毒 由後猿和意力 承第液 $=$ 尹 六空依比 公是少䡬

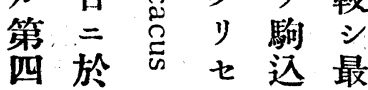

y $x=八$

下弱對常要

ルモi最

モ, 毒王旨

力二男探

, $=$ 收

シ八頗

于例公便

製公軒子至:

夕竎痘

向少励

可猿、后

1) $\exists$ 而 三

才過产使

今過猿傮尊

汽

ク公對多焉

チл少》突

亡下儿:

八毛毒分

動牛力必卜

物體,

及二强玉是 炎威车等 人染毛便, $=$, $\exists$ 理 對 $シ 7$ 威 由 スォ用ゼョ ル能将り 毒八ルリシ 力ザ卜キ , $N \neq$ 予 微刃八唯等 弱縱爾何 于 三後故從 际人來 二又牛 卜辛體患天 ᄀ>接者然 經潼 $\exists$ 痘 驗テ三異毒 


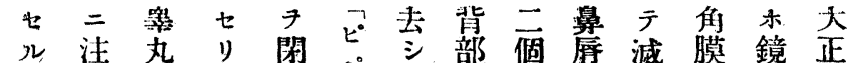
製入ン制 苗七先水 ス卜菌虔計粘七右度年

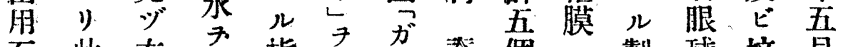

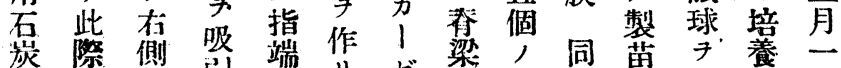

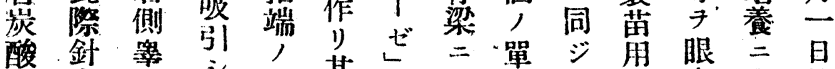

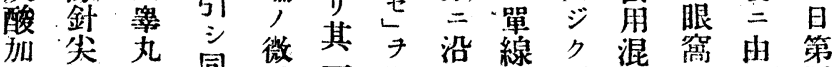

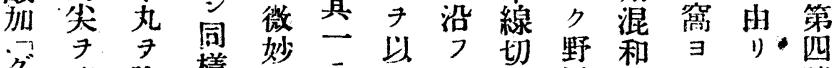

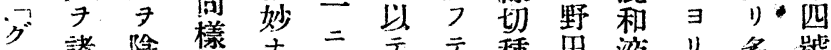

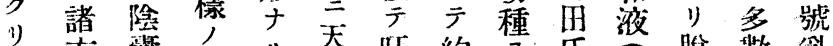

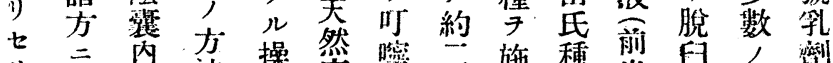

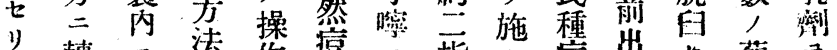

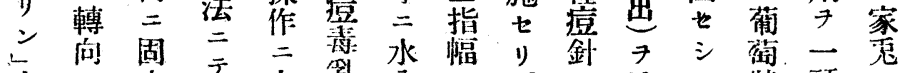

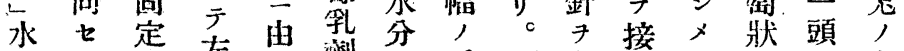

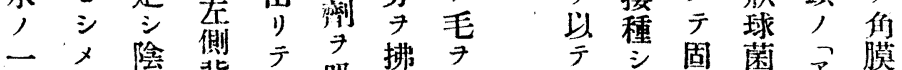

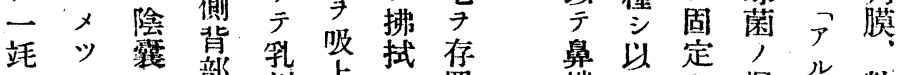

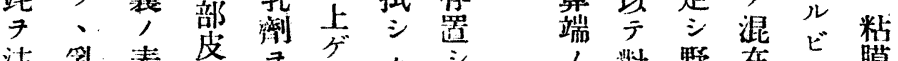

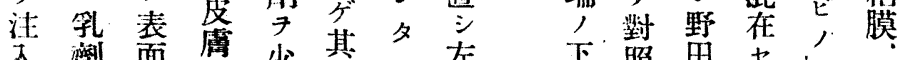

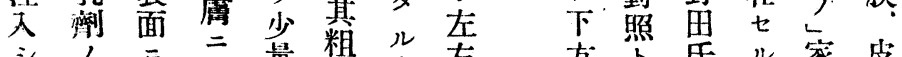

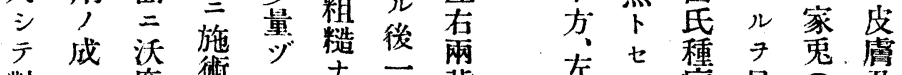

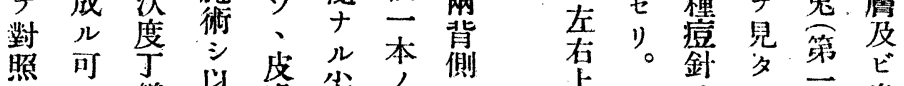

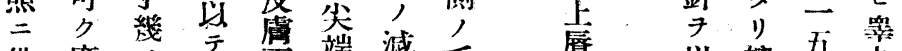
供 廣 尹

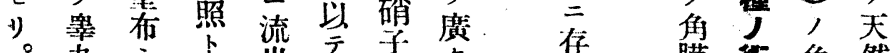

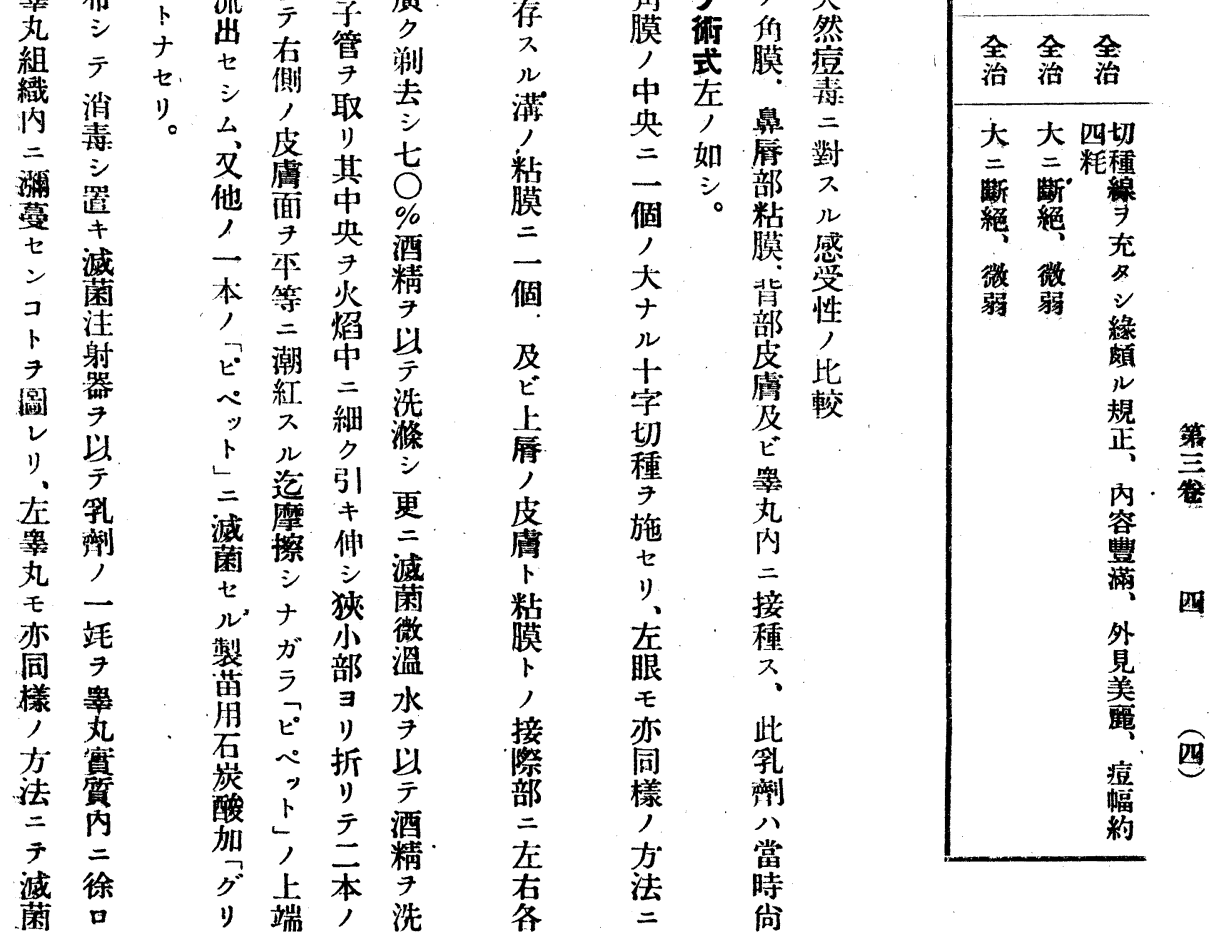




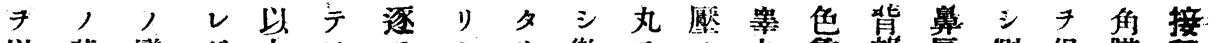

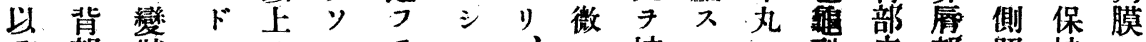

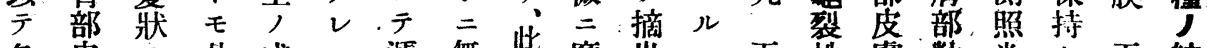

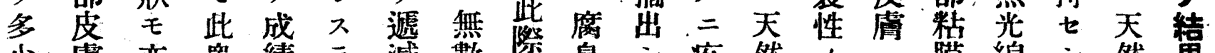

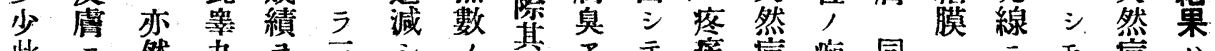

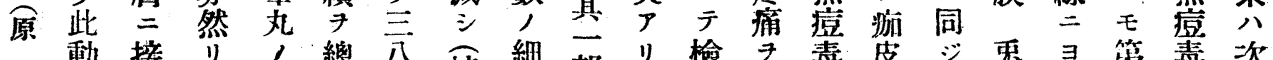

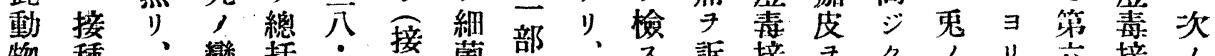

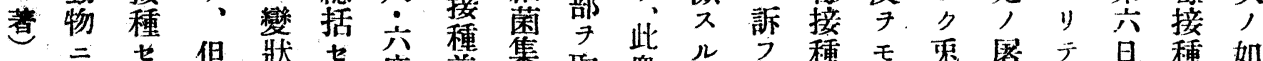

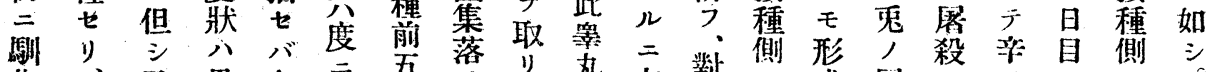
家 化 苗 予 果 角 等

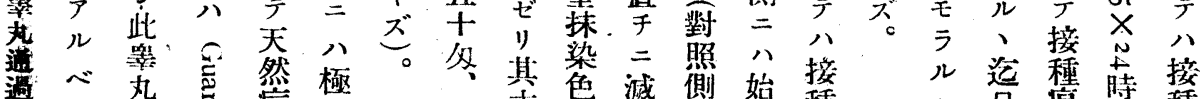

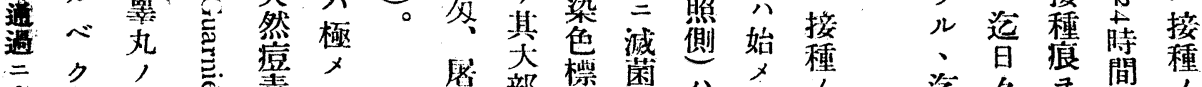

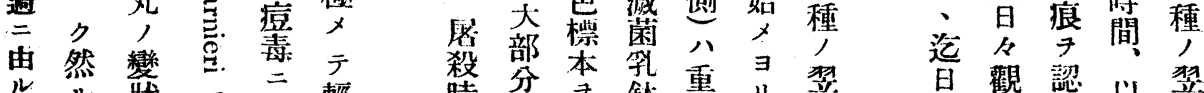

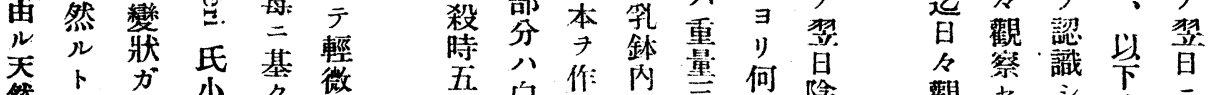

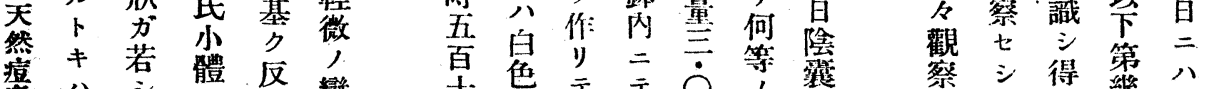

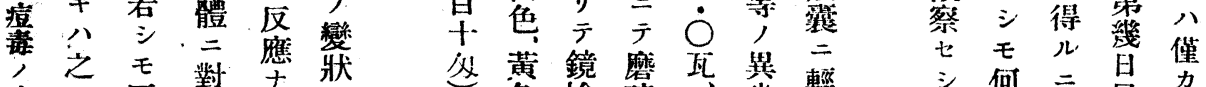

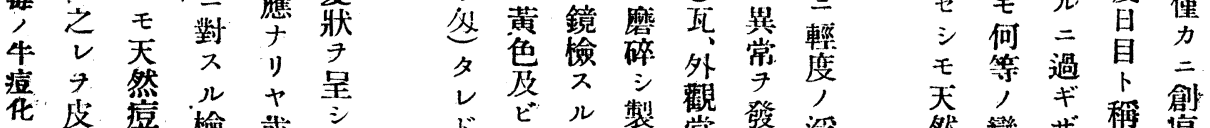
就面 毒 香 或 粘

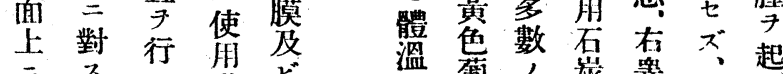

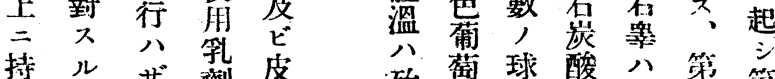

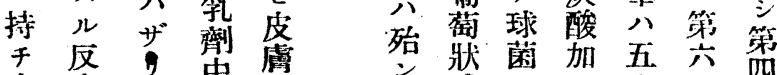

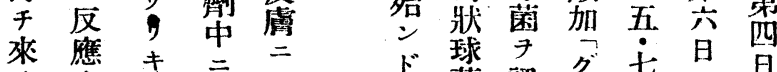
大

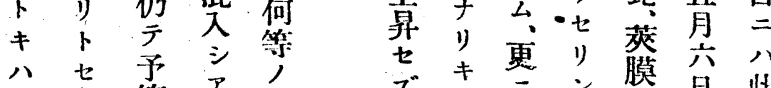
必 バ等 ア反 反

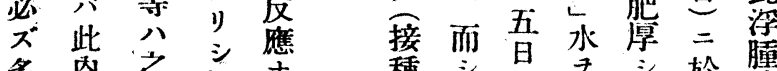
多芮之 緗ナ 種 シ

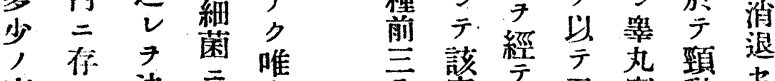

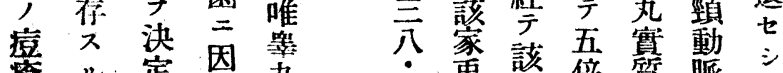

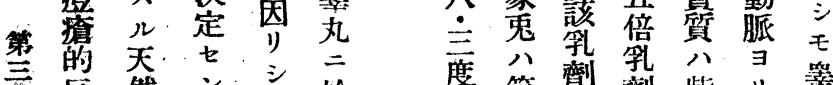

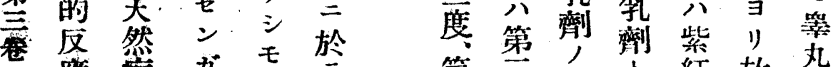

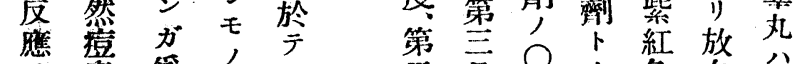

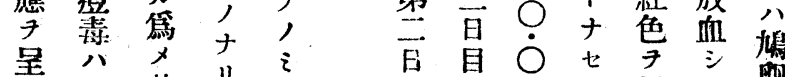

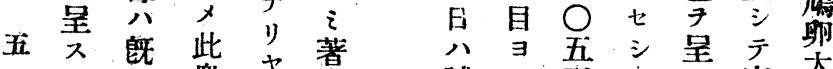

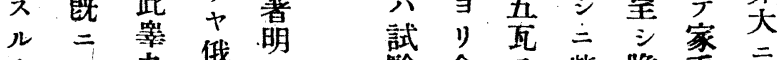

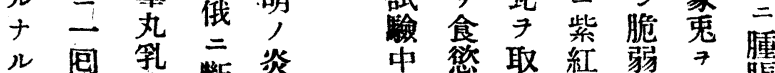

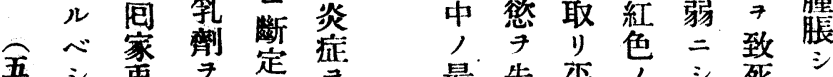

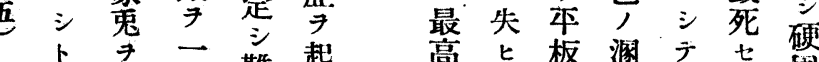

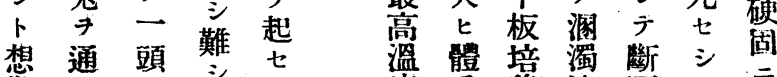

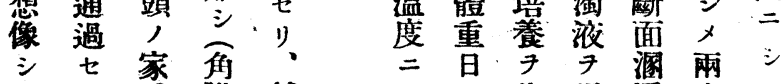

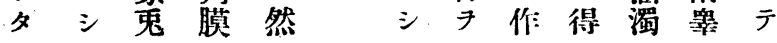

種發顕皆四 㑡 七 照 此 十

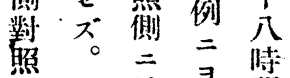

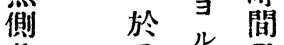
共 テ目 遂 接 公 八 何 種 於 接 等 豆家算 , 創兔微 度癄虚腫 于 証殺起 呈 メ ズ モ

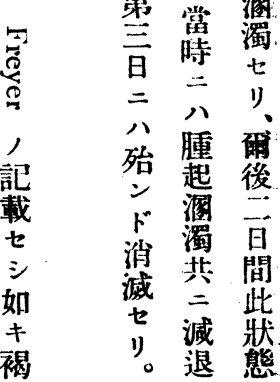




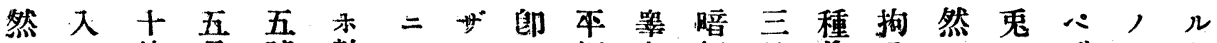

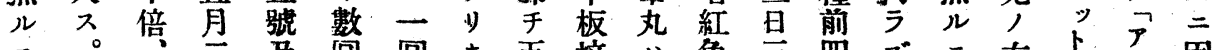

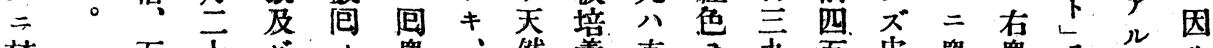

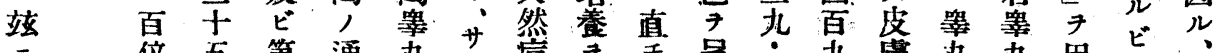

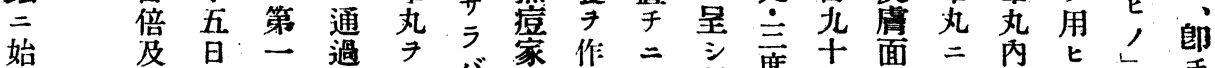

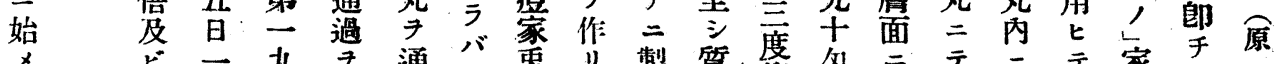

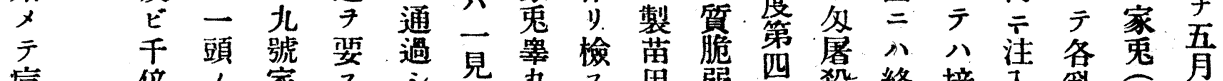

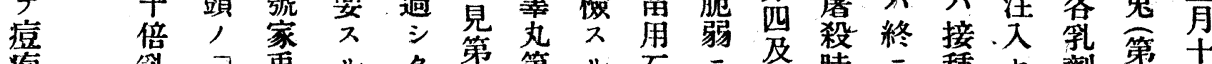

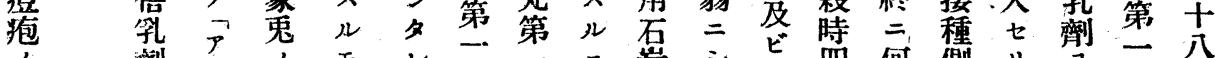
形 䈀

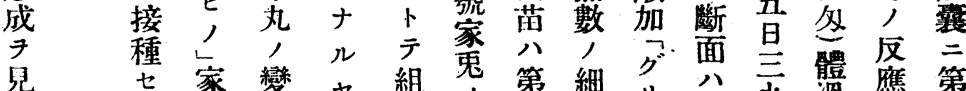

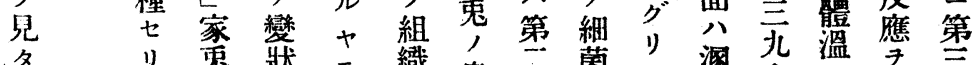

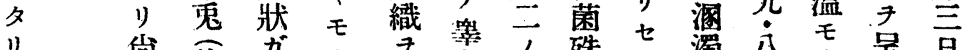

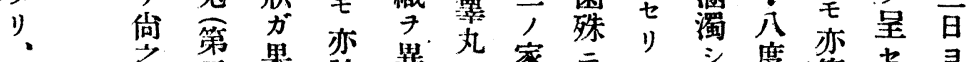

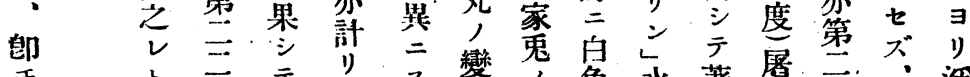

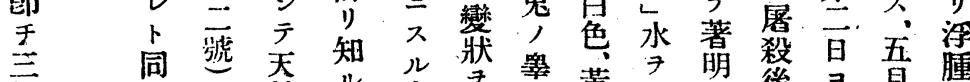

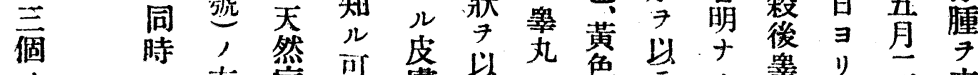

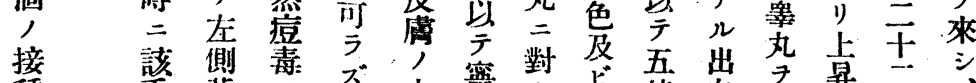

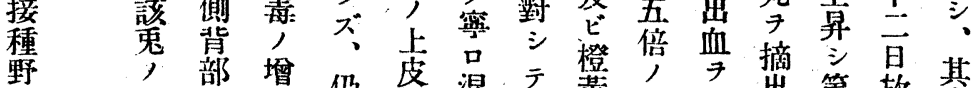

$=$

何

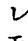

王

第

百

小

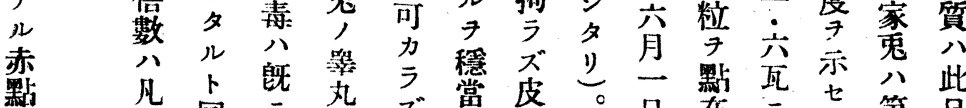

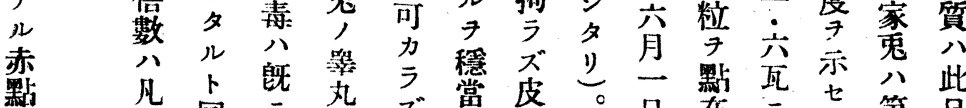

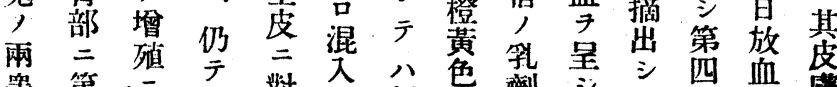

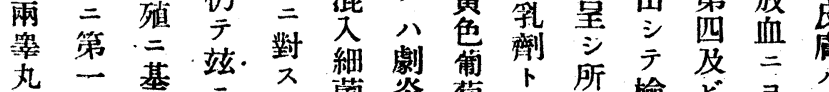

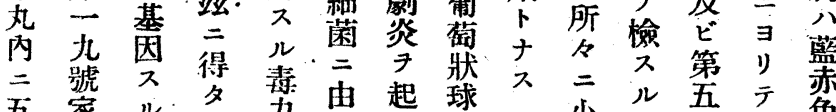

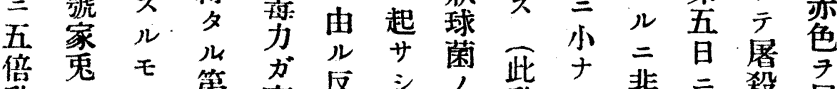

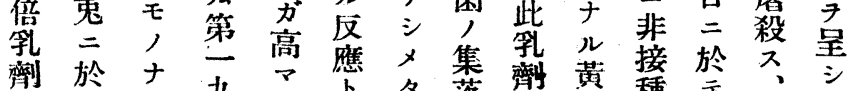

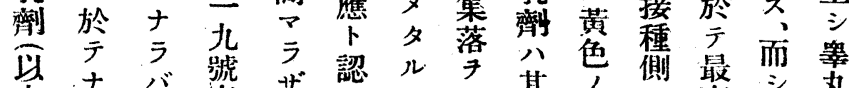

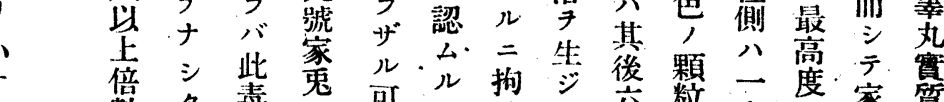

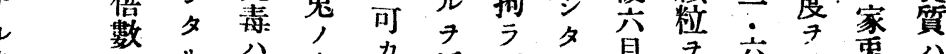

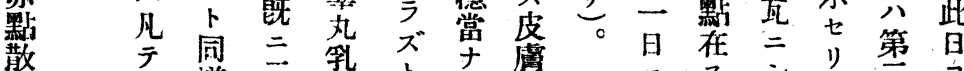

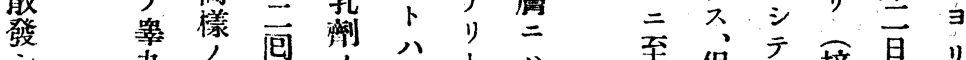

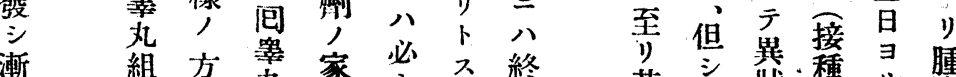

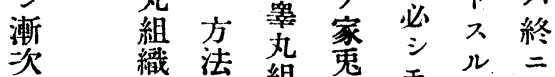

元

第

五

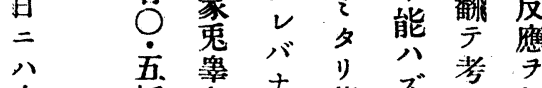

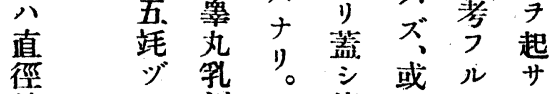

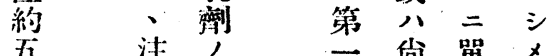

五.

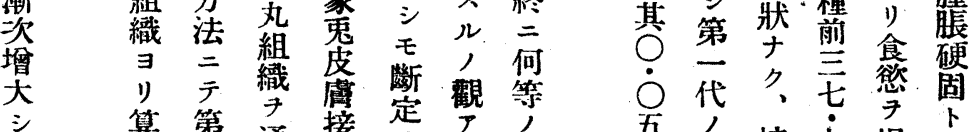

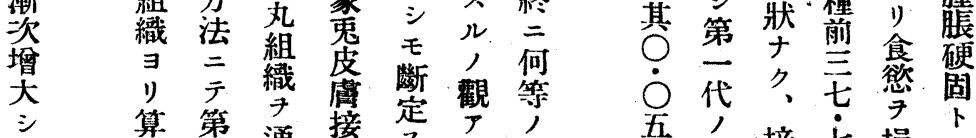

元通種入と䖒

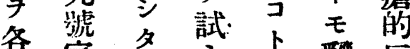

第少單

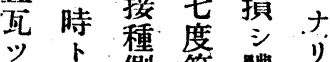

$\because$ 異 第 體 厴

取㟲 三百重痛

取鹰: 官旦漂

テ臭亙分焦

枚算度方办

各杂家

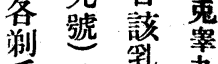

毛: 乳势

面在岪通

别背生三

々 肋理 由

二部食天

接 三食然

種長醷 㾀

り約 亏 牛

少糎更嗐

之幅三”

絇倍就

同糎干

時 倍

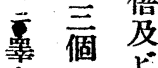

龪卢

㹈 百

對毛倍

青稀

力

$\exists$ 新

モ。列 鿷

檢七丸

七: シ 組

ンメ織

ガ前

䉆述十

x, 倍

五代 、壬等固 稀 如 百

ザ粗䇛及

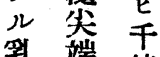

乳端倍亲

人有嫦

犝 少

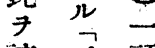




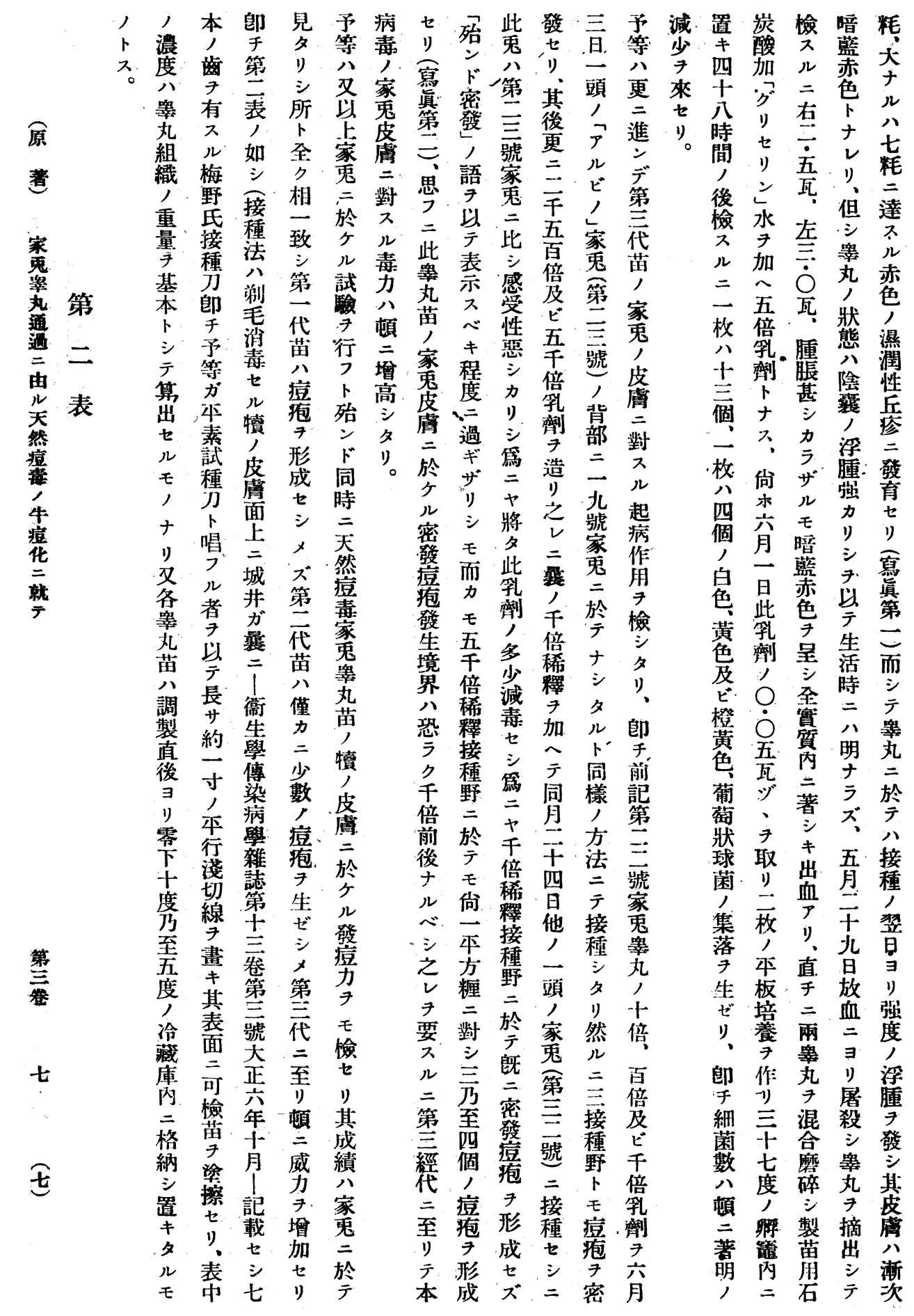


天夕スシ拘以普其》及而 然レムモ今通數厅厅シ

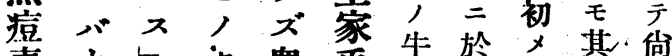

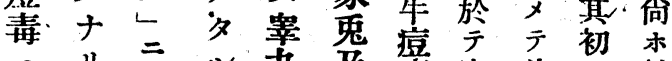

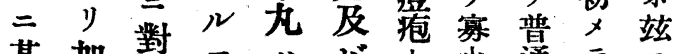
基加

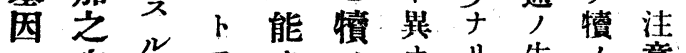
次馿 7, , 光生, 意

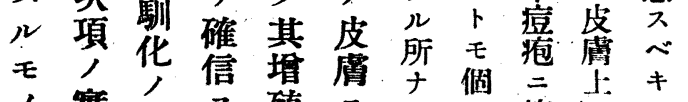

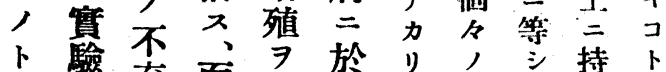
卜驗充而 7 於 》人持卜

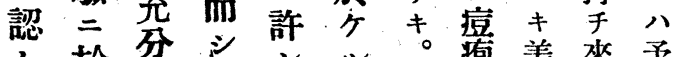
么於分三江。疮美來予 心云方而接公麗六等 キモ歸第卞種然な僅經 モ此 䒫帒成美痘三羷 人關儿菩該樍麗疮微三 二牦 シ 分窝毒基

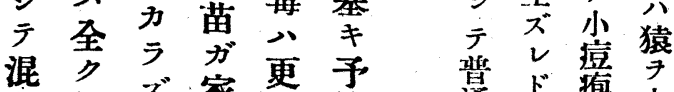
在相 ゙、家三等通、゙疮中

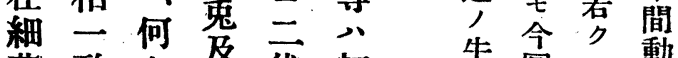
菌致 $\mathrm{r}$ 花初 モシナ踏三代 亦夕 2 覔三接 罗》。化代種 少、帒拨下兔 此隨 、愿此, 病亏重於種皮 機第元於動盧 $\bar{二}$ 發物及 夆代 二祭, 興接從㾦莘粘 七種亏七无膜 菟階: 学 当段文通天 卜峷的得過然 八无 $=$ 节痦 疑了皮湆 七病佣, ‘ ナ變二荲漸感 必對冪次染 千其入意此 畢大公家培蒙 竟部毒鬼地亏 次分力 $\ni=$ 級之高儿那》 的 $\checkmark \rightarrow$ 化 , $\Rightarrow y=t=$

痘向公動

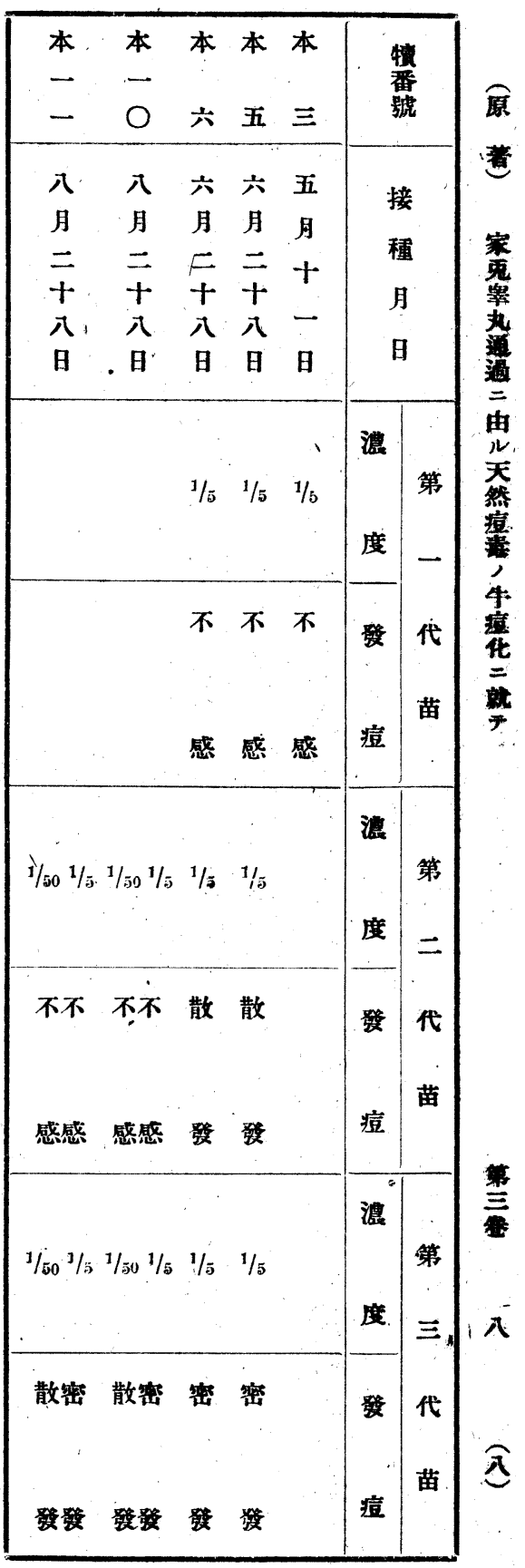

過分後 赫令至向

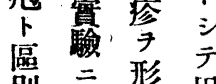
別云晟用 入八公 第儿多 在二場 能侄齿会 ザ杂宁公 苗更之 コ宁慣 卜否等通 之, 螺通過 乙, 過七 †皮 其藏公允 他云么

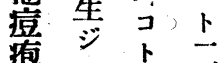
䉬夕雨间 会儿音若 , 痘间当 殌疮, 八 


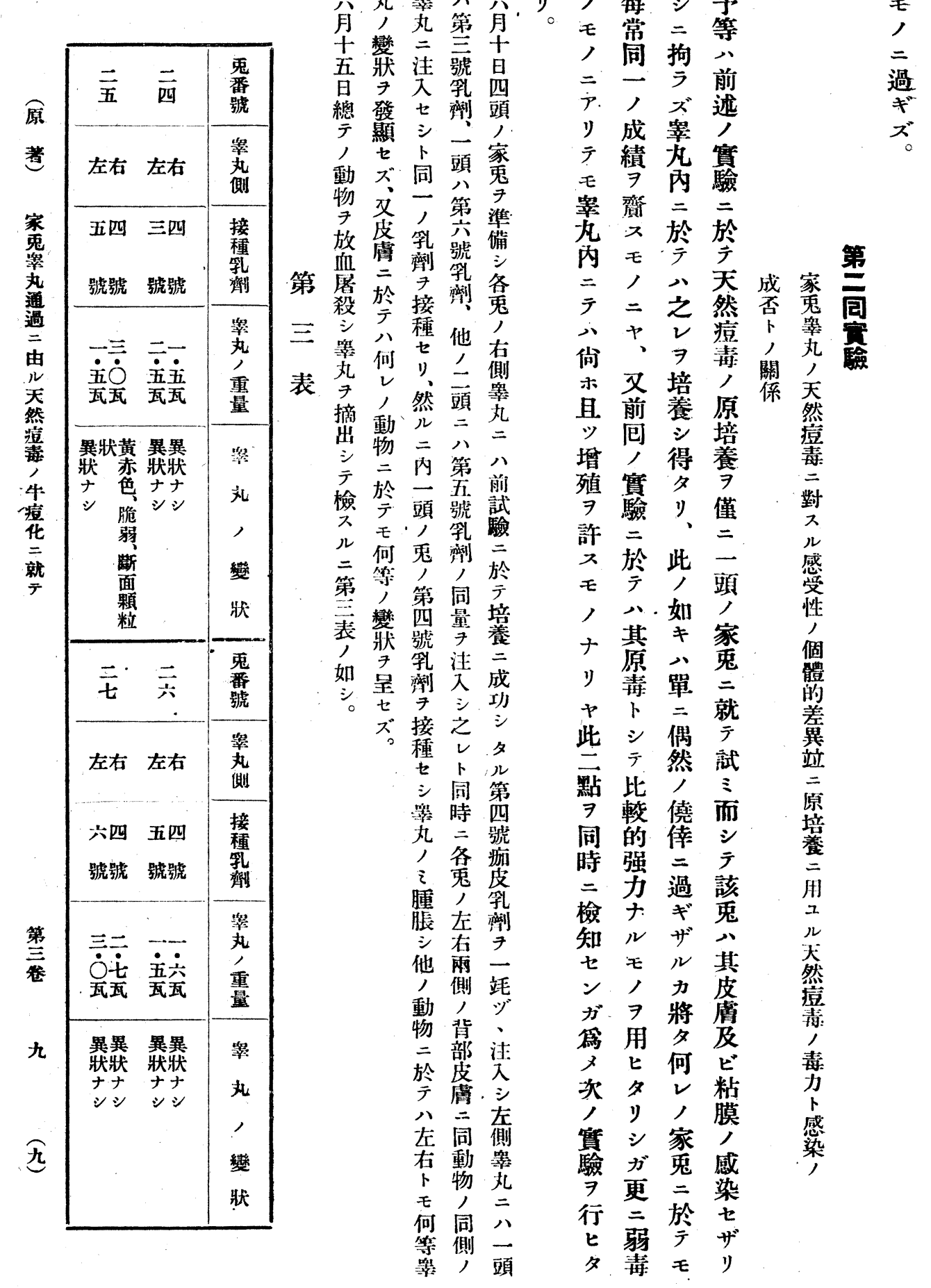




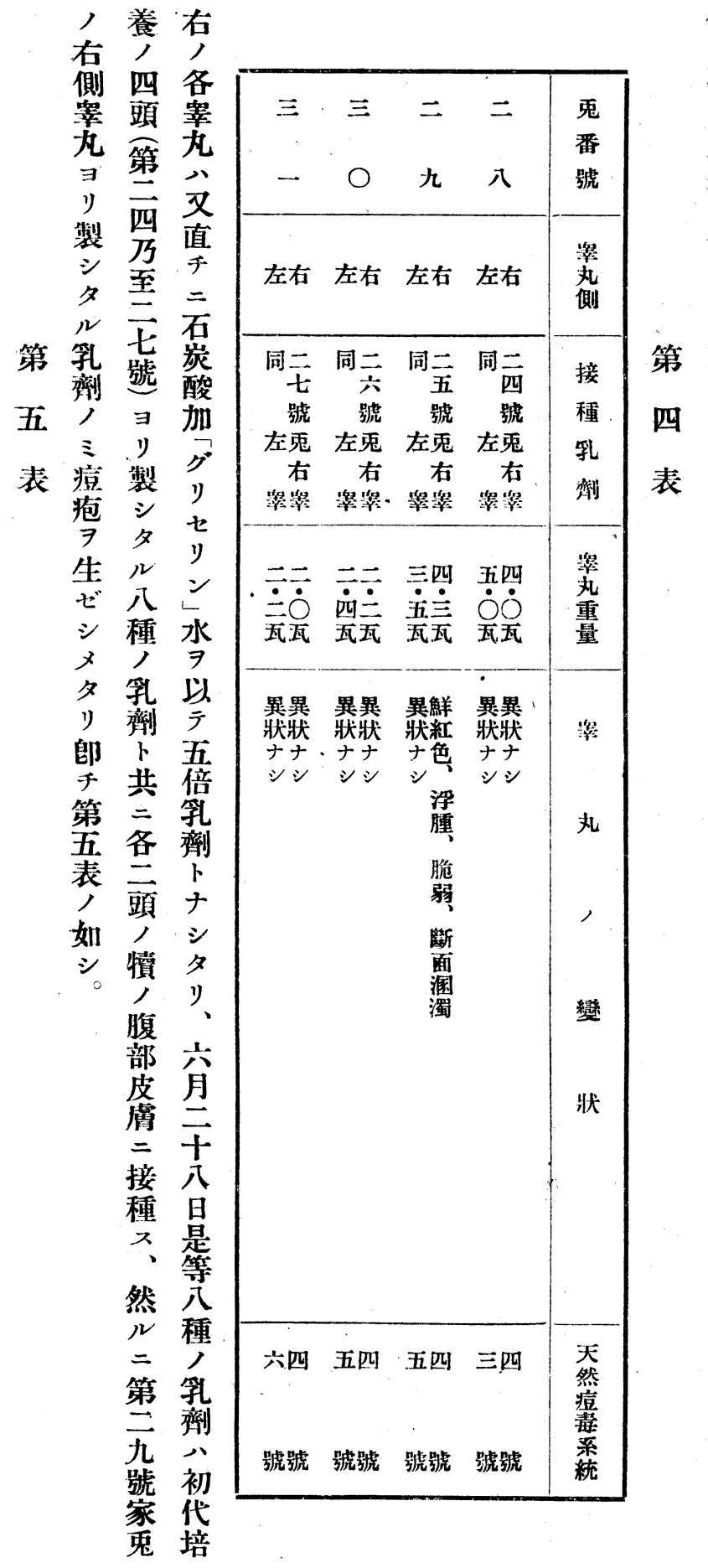

侧り人, 病 殖此 二製學ナ變方, 於 $三$ 丸 $三$ 單 如 テ夕二六起二 モ儿注月病第

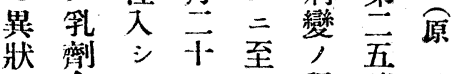
ヨ タ 一无程號 著 呈接儿旦ヤ度兔 七種卜更モ钼, ザ七同三及儿在 リ三四测輕側

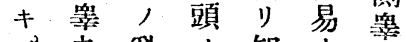

家
突
势
過 荝鬼儿次 炎接各力過, 宙 症種學亏ギ七等 尹 せ九 ズザ個矢 起り二トル, 然

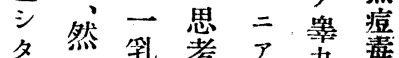

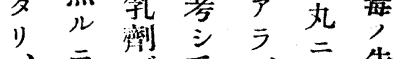

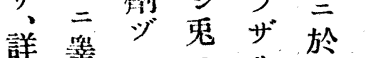

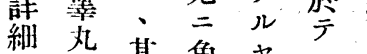
八二其角 第於靖個㠜甾就 四等個疑眼

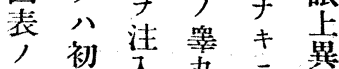
如垈入丞二牀 シ接り何モき

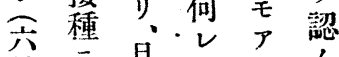
月公县无台 干方變 直爻能 公彎々 日同製バル 放顯時苗佾モ 血筫筫或 虎七冬石闹或 殺三兔酸家是 圣等公酸鬼是

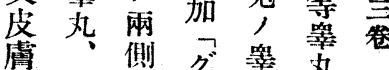
二郎, 》九丸 於手背七文於 テ第部り注乻 何五膚兄 久 ᄂ 號二水儿天 , 鬼同 $\ni$ 卜然 家 分 以未観 兔右動示八毒 , 側物五涊八 何罢, 倍么多 乙九同乳べ。少 , $\exists$ 側猁キ增 
又前二而儿乳威以

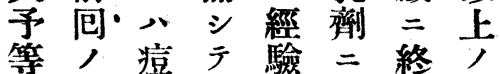

八試瘡右 $=$ 米曾

原前驗的,

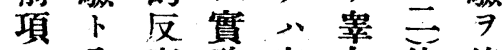

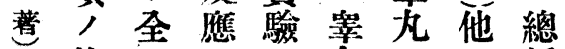

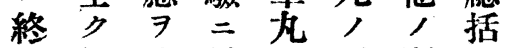

家相惹於占羅弱七

鬼二起方皮病妿心

勨於致不虚七天一

楛第入。單; 点然三

通第。

過而䈭毒四

由回能回病 $==$ 號

天筫 只家於厅乳

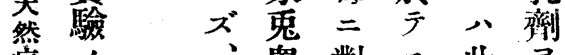

㾀，睪對 $モ$ 此 $尹$

初第美天皮, 䙵

车代

癔培䒫通感分㐫

华二過受同感二

就草到清性受接

禁杂多八乳性種

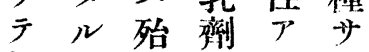

病初, 夞, 比

變 ヌミド毒動タ

$\therefore \quad \bar{\tau}=$ 常性物

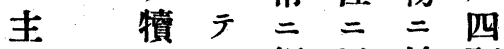

贞, 八相抵於頭

流皮雷尔抗示,

天 膚二行

天 二悓ス夕ラ兔

然痘 $=$ 。 y發,

癔疮於笲内

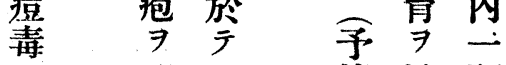

二 形, 等遂頭

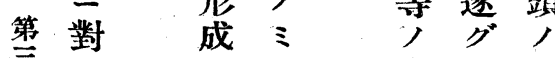

粪莎

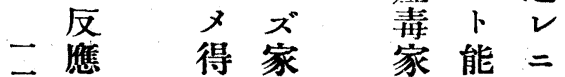

二聭鬼公減

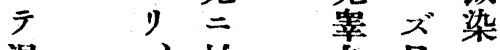

人混於无县

三在郎示丙他

こ細 チ辰气接

菌此 5 種 严何

$\therefore$ 關 其 $=$ 第

假係皮於四モ

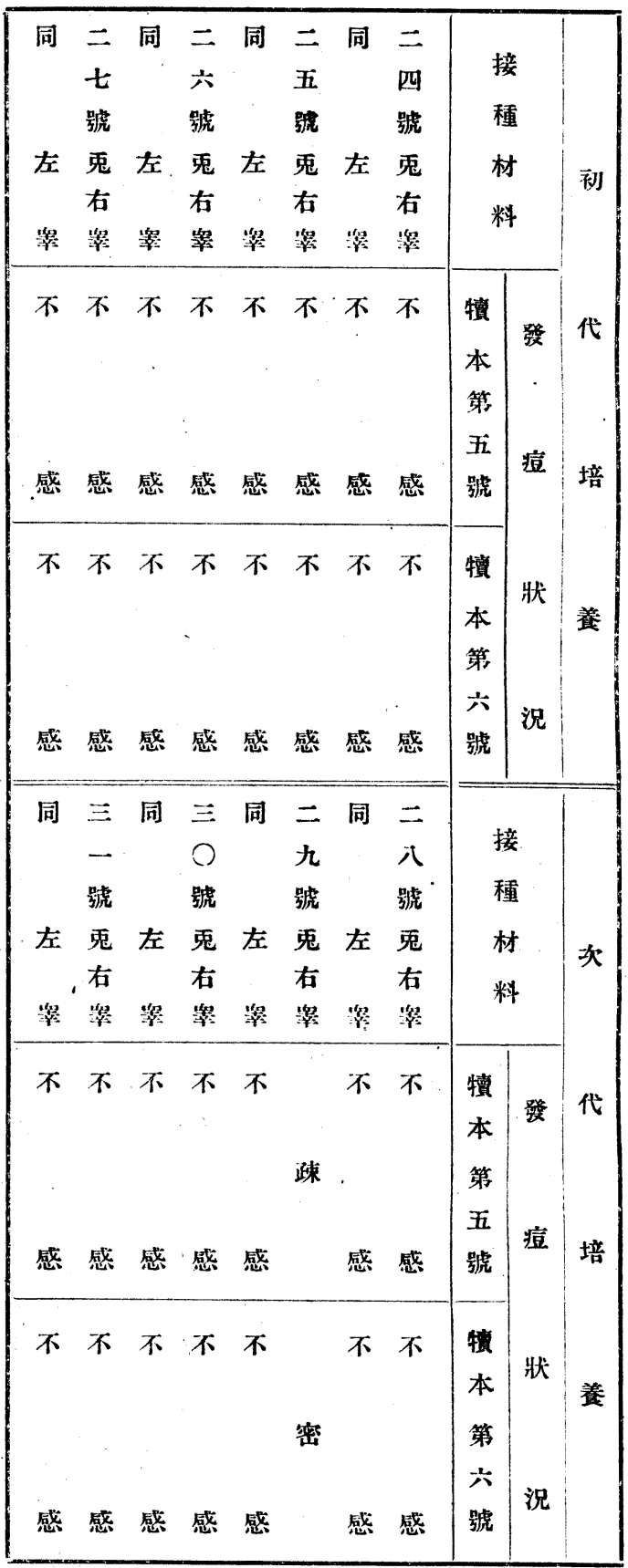

命八䖉学號不 
痘痘予

毒 狍 等

八 7

朁 形 第

二 成 一

牛七司

痘 三 實

毒メ驗

二而二

變 シ 於

化 テ

七 天

其然鬼

二痘癔覃

卜 炮敖

$\exists$ '

確外家過

信 觀兔三

シ 站, 由

夕二睪

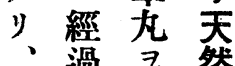

蓋, 通 痘

シ 通 過

予常

等人牛

牛 痘

溒癔上花

體 三三七

及異问 三

七 $\bar{J}$

嫧ザ至卜

體ルリノ

培 二管證

養卜二明

$=7$ 家

見鬼

リ，

天りミ

然 シ ナ

痘 ガ

毒 是

人等 犢

牛,

痘 點 皮

化 $\exists$ 膚

$\exists$ 比

行 $シ$

7 多

二天 數

當然,

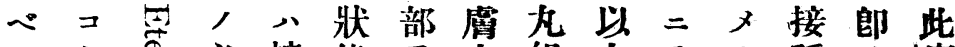

カ十9 必接態 $尹$ 上組上テタ種・病

ラ 7 要 種三别皮織三八ルシ 此機

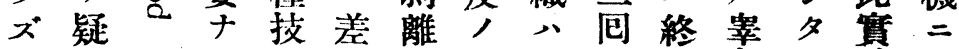

七八儿術異サソ慥人三丸儿驗干原

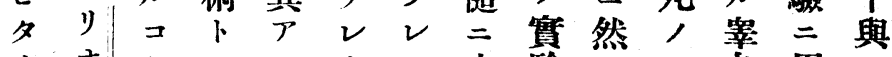

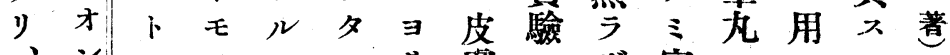

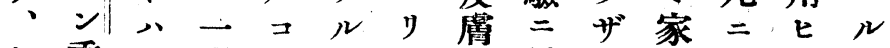
猄委定卜皮毛当於り兔, 夕卜

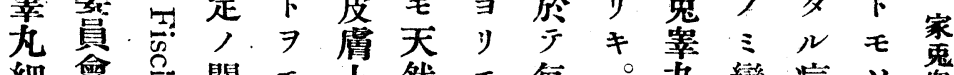

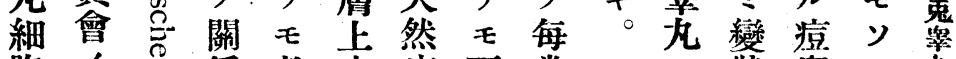

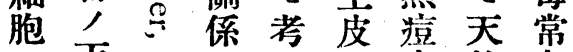

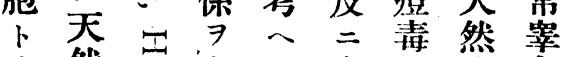
皮然吾有分乳椠癔

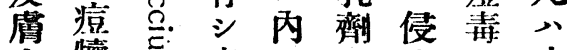
上凟 的痘二 皮體尔疮置塗レ威虚 細接学学易染学 胞種究形ザスキゼ 卜試导成ルル素シモ , 驗吕七心卜留 ‘天 天人和力覃易然 然成く邓 港 績 品 ン ズ內 ス カ 毒

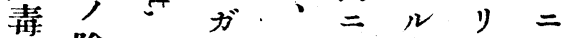
等陰

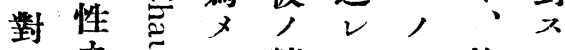
ステ方二㹙 $\exists$ 然ル

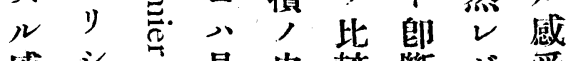
威 $シ \cdots$ 是皮較断 ゙受 受 等韭膚的 $又$ 性 性恐, 下多儿單, 人ラ唱飞天量 素 ク 病然二卜此 留病 ル毒癔泩能事 ル

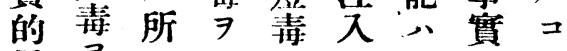
異 $\exists=$ 二 $\exists$ スザノト 同刺シテ接ルルミヨ 八種テ上種卜べ 份シ殊皮 シ 八シ 以夕 米多 $=$ 下各、示、 今 令之細何值 後シ 究廣 $レ$ 胞卜千然

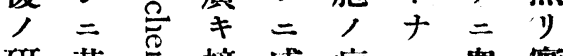
研基名接威病 究因志触染瑇 バ丸驗 二せ面入二角人, 俟 シ 导 夕ナ兵與上接層胞果 ザラ及>否、ス, 八 ルンビルトル上皮莘 $\exists$ 狀薜, 热 更寻湤 單道 三認皮三過 一。乳次由 包他秘級关 通, 公的箱 過七何, 䈐 三個しモ棈 夕, 毛, 乐 尘裳二癌 後杂時過华

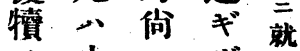
人少ホザ、笊 皮多多儿 虚卜數口 $=\mp, r$

㾤肉球 7 疮眼菌述 $\exists$ 的 7 心 モ゙八有り

正 ×常夕力 得睪り此 夕丸三算 几 毛異不第 他学拘於嘗 ，第 天

七所 -

棝吾抟三

異然兔 鼎皮为 + 二第確 力此四證巨

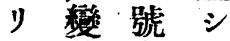
鼎孚多 睪习劑》 丸認 7 、 生 二混夕 
亦・毒 郎

緩 力 $千$

和人士

二㿋字

原 苗切

テ卜種

著普看

通 做 於

家牛 心

器翼而比

痘水 シ

疰 所

牛十接 佳

痘力種 良

化り部,

就 手, 痘

厂, 附苗

郎 近 1

于 二同

接傍一

種發

七 痘 發

洈 痘

痘, 7

苗發ナ

八生 シ

最モ 夕

早又

天 全

然 身 $モ$

第痘 發 單

番 毒 痘 線

ᄀ $\Rightarrow$ 接

性 モ 種

三質爽

），成

失 ב績

$\therefore$ 七 $\exists$

三全ナ少

牛 全

痘身心

化症，中

七狀等
二邦五密氏乳以反》

對兰倍發接劑亏應犢

照 氏量隆種 7 普 $\Rightarrow=$

卜三壬越刀方通呈於

シ 依石起, グ向七皇

テ賴炭高幅七方ザル

效兰酸?、員り法ル痘

力 力加表・事

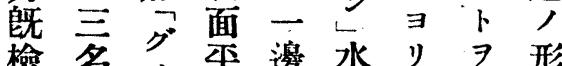

检名少尔邀水り 7 形

同 同等二 ノ人坦卜

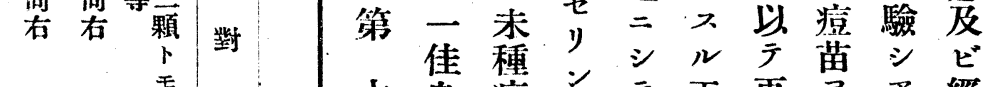
兵良痘 痘兒水接方二, 製 $v$ 過 表苗二中種形四至心゙

习之 = 部 $习$ 倍之ナ普

以、浸ノ一二レリ通

厂 9 清皮呠稀 9 ,

二接济下釋人站牛

個種同二稳 シ 體三痘

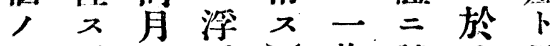

十、五腫二牝試息

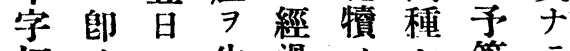

切于曰生過人七等

種 各导 ビ順右ン ザ

$\exists$ 兒 壳 ズ、調 側コ第 ル

施、, 虽二腹卜示二

七左䐴同 $シ$ 壁 7 司. 王

リ腕・碎、日广企試ル

二 器此第皮圖羷卜

其一二痘共虚

發個厅疱日二タ第

痘人，磨寻梅り、至之

，單碎抓杂野、經と

牀線 シ 取百氏郎代 7

況切痘 シ $\vec{日}$ 法于掌人

八種苗厅旦二八炎體

第 $卜$ 粗二ヨ月苗二

兵一十苗於り三第接

表個シ言々接士第種

人古分種八 二

如士月㘸接

シ字三皆種 ル第䗂モ

切士得部 $三$ 三兔毫

豆夕狀四號犢天

行同り態坪家 二然

七僚值八人兔接痘

其并千痘梅睪種毒

傍上二疮野九的 


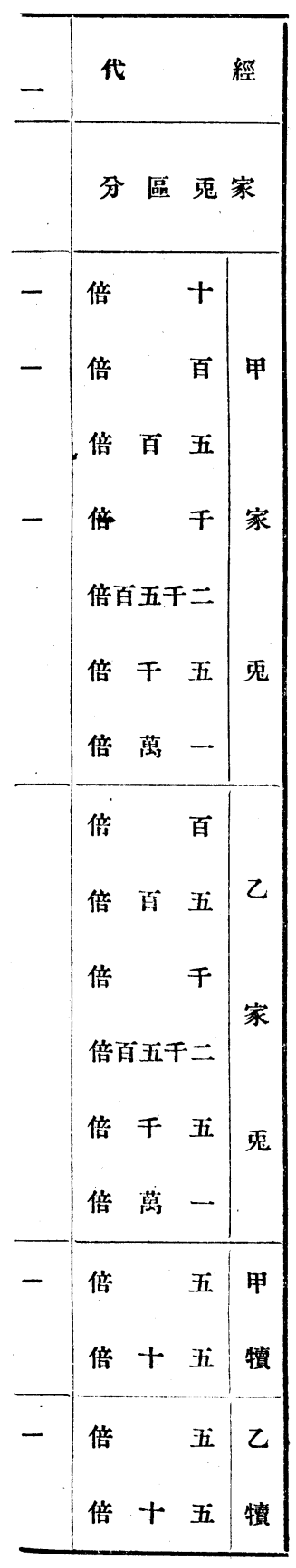

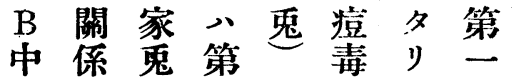
肉 范共 $\exists$ 然司 太第 ビ 日リ完レ實 , 七一二始全 活 表 部 於 $\checkmark=モ=$ 字, 八齐家倘 於 习 如又放 テ兔普 天 用シ䫀血經·萃通天 七刀, 屠代无, 然 夕密皮殺培三牛痘

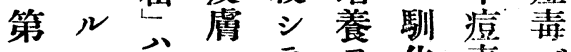
七, 痘接菩試货毒, 坖

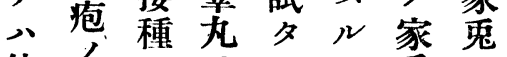
表
思 毫 睪・シ

八モ丸 $\nu$ 天 队 ズ然 $=$. 況痘於表原 ン 毒 示 分牛著 其 性 痘

犢 質 化 但

家發乘少此鬼 鬼痘失卜試热 睪 狀 シ ナ 驗. 道 沉況 $ア$ 二 過 通了三八用曲 他密

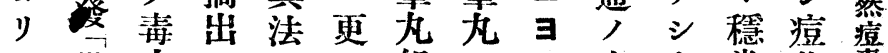
モ世力口 卅 毒心 力殆比 $、$ 經二過然 强名較 7 繼代完 ス痘接單ザ兔华

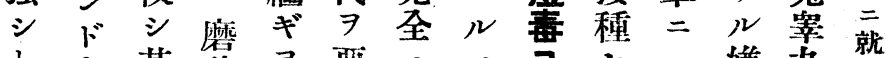

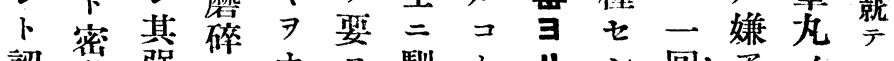

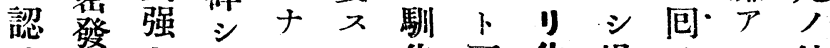
メ然 $\neq$ ス 化三化場, 次 +t E 石心゙+シ代生合犢モ倘

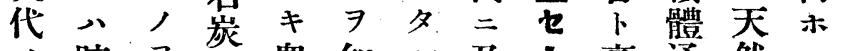
踈 $\exists$ 酸萃知 及

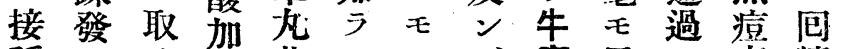
種十リ苗ンノデ痘異ノ毒㹙 ニさテグ 供 八次り三篇比兔少 シ散人セ頭メス质家ザ由兔膚 夕發植り, 第レビ象ルリ䙵

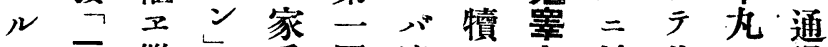
二 二 繼水鬼回遠了杂於此 $\exists$ 過

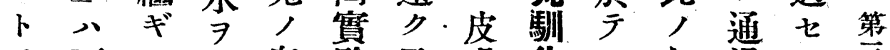

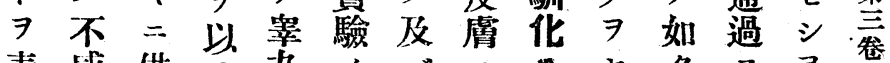

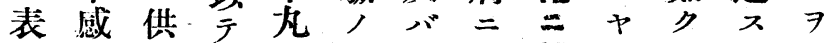
示 $\rightrightarrows セ$ 五二第 ス對就。完ル以 ス示り倍接等依

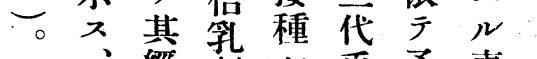

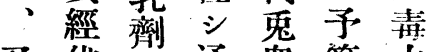
又代占通睪等力 家包常苗心方 兔 數 ナ第咍此 頓 區占 吾第, = 分毒之旦三如增 少、稀三强 A, 7 號㤽 $=\vec{r} \overrightarrow{0}$

牛三然

化三毒 西

べブ 既

シ $モ=$

卜佾家

八水兔
痘可痘 
原公吾西 主

著
BA BA BA BA $\quad$ BA $_{A}$
B A B A
BA
B A
B A $\quad \mathbf{B A}_{A}$
B A B A

家

密H+ 密密 +t+H 密 H+

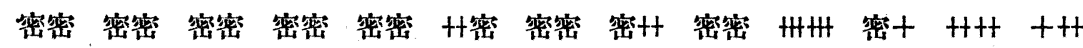

密密 密密 密密 密密 密密 ++ 密 密密 $\mathrm{H}++$ H密 $+++\mathrm{H}++++++{ }^{*}+++$

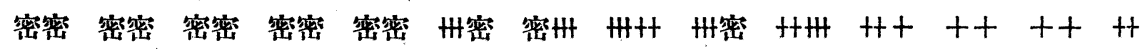

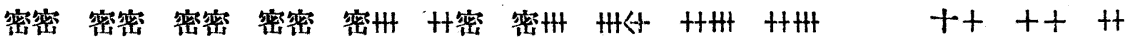

就

密

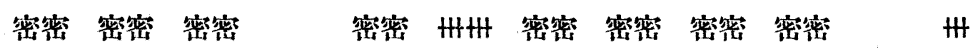

密密 密密 密密 密密 $\mathrm{H}+\mathrm{H}$ 密密 密密 密密 H+H H H

密密 密密 密密 密密 $++t$ 密H H密 H+t H+H H H

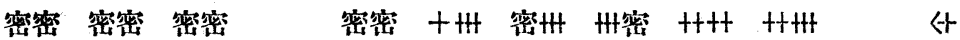

第
春
$\stackrel{\text { 五 }}{\text { 吾 }}$

密+H H密 密密 H+t H個 密H+ - 密 H

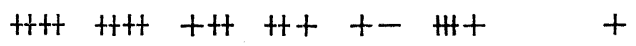

密密 ++ H-

個. 密 +

<t+ $-\leqslant+$

$+$ 
六五四三三一先倍毒十亏表

り = 過笔力經最二

モ初天アス單家家家 速 然りル二鬼鬼鬼 力 痘テコ一, ,

ニリ毒モト回睪睪若 家家 ガ其二家丸丸干 兔兔家犢问兔内 個 莘, 兔 二 二, 其體 附无莘, 與至莘於皮心

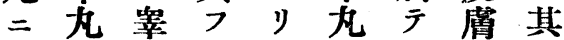
記 馿内 ルテ 化 $=$ 痘初通然り丸 入於通疮 メ過痘 $モ$ 内 厂過人テシ 毒天二 天形此夕 天 然於 然ル態能ル培痘テ

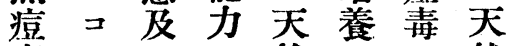
毒トビ $\exists$ 恐發享痘 $v$ 咸痘 リラ亩受毒卜染毒 化ク, 齐入七, 生三經三未来增 包過包名時丈殖 夕二八二家八易 不普及兔一許 牛心通心友定。 㾀 バ, 心 毒完牛頓情暨 全痘二, 上 常盍强皮, 二牛二力磨毒 牛痘由占二力 , 毒皮痘羿 皮三モ儿在有

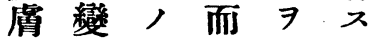
, 化上文生的 ミ元異テで材 $\exists 儿 于$ 既 三料 通毛为 過，所三心使 类子向二角 秝如三罢下不 yシ。能 夕。 $7 八$

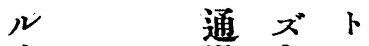
生過之 痘 毒 七 $v$ 要 ㄱ 7 整通
㹸三代强於 牛 习達 7 度厂

痘以㴗要

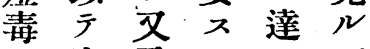

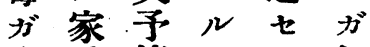
此鬼等モり如 結如背野、抑第 部口如了圭 論·早皮氏江不代 ”虚報、絕迄 既二等例 4 二密, 體毒 完笅復心゙度力 登痘試野履可 疮二口組ナ 此 於氏織》 組生亏 ガ, 動 織 ゙゙、牛ミ摇 $=$ 第痘 $\exists$ シ 馿公美䓯通夕 化 七 =九家 至代鬼桃王 $=\nu=$ 睪り以 卜乡至太柴後 、、誃丙牛代 注然于純痘 $尹$ 百, 初粹毒重 z $=$ 又培 心初于養家先 キ邓本䈭卜 コ妇系行睪共 - 家丰組漸 ス槐三場䅧戠 睪代合二逐 无，完 丙毒八全亏 二力第三增 於師兽馿强 天手化 天睪七 第 然无代古 痘組 $=$ 毒織於八代 $\exists$, $\bar{F}$ 大 y五最約至 卜》第正无

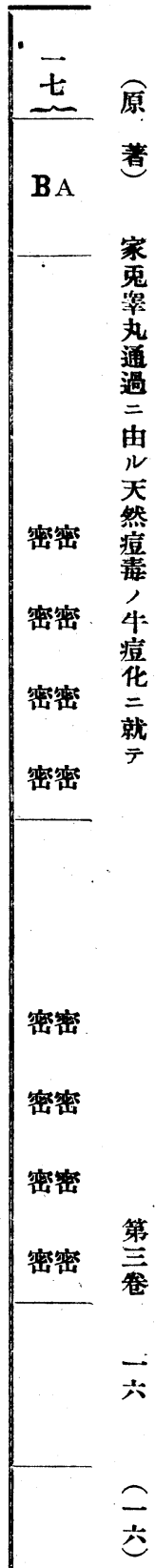




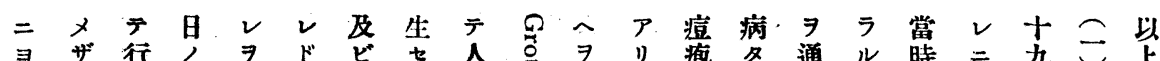

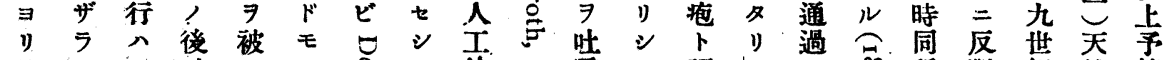

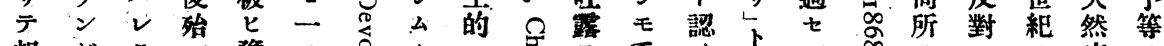

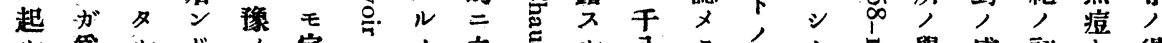

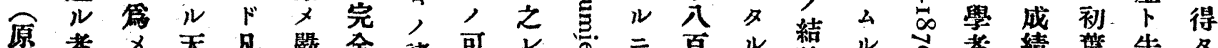

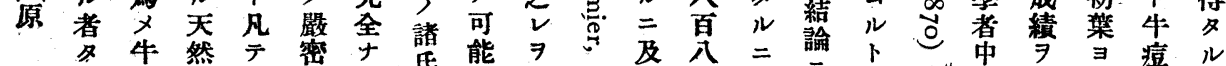

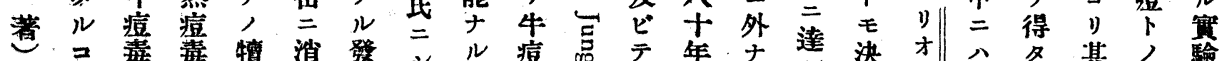

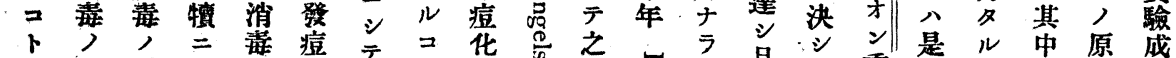
家今偶動於七寻 氏

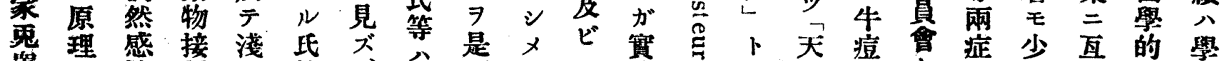

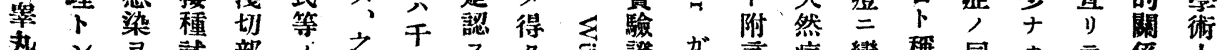

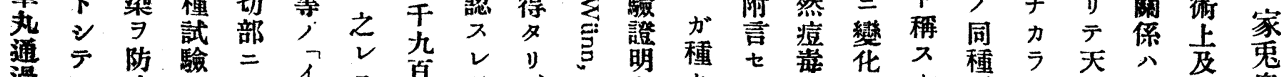

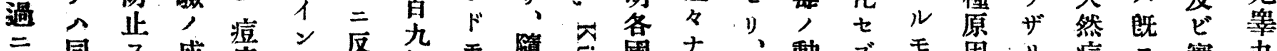

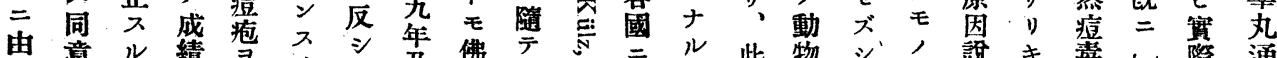

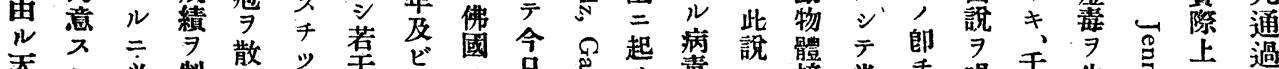

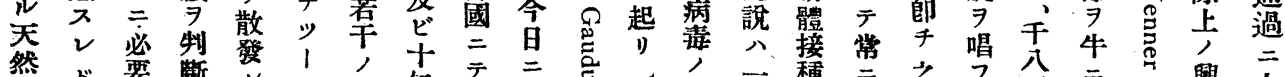
然 $ト ゙$ 要断 义

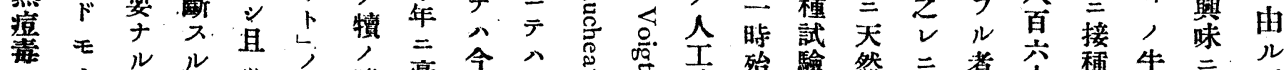

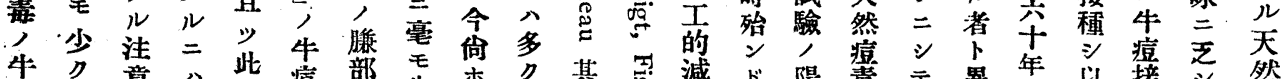

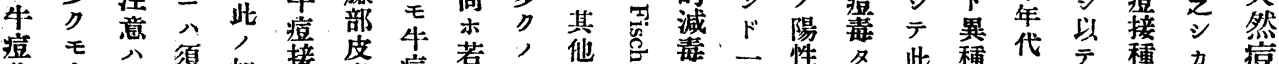

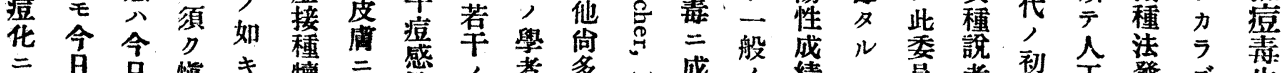

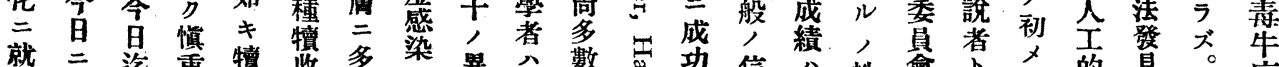

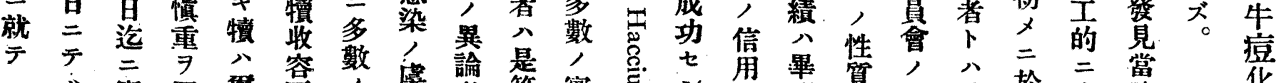

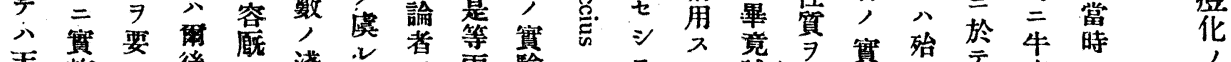
然サ施 、後警场

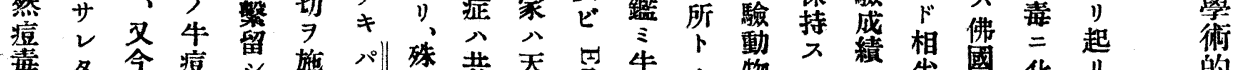
毒 タ 今 痘 留 施

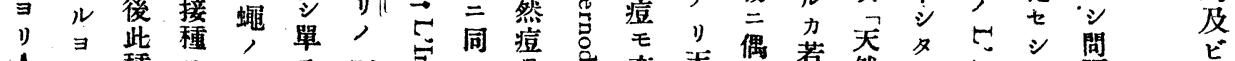

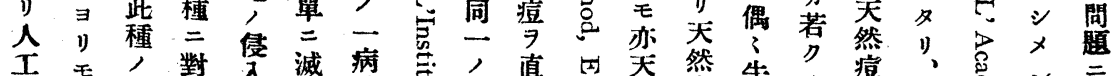

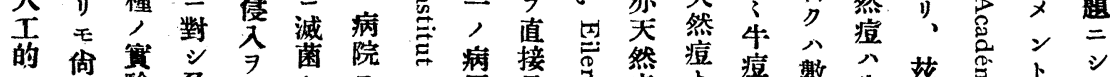

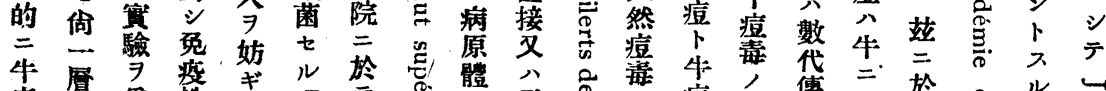

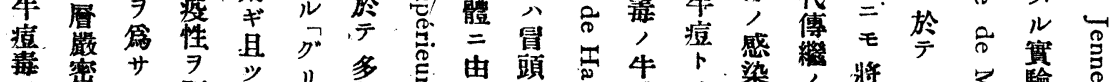

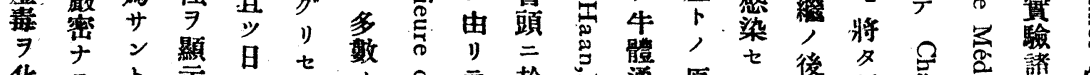
化 ラ 第生 ザ

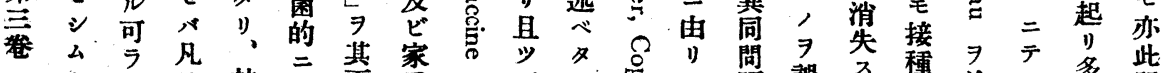

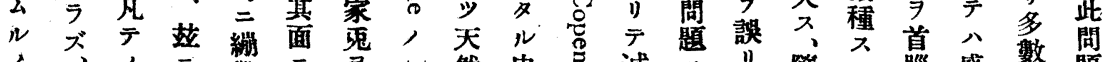

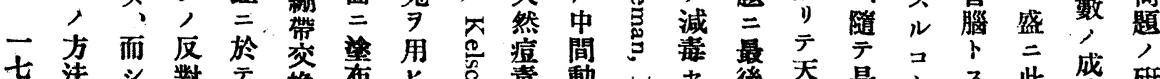

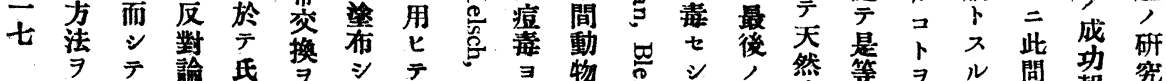

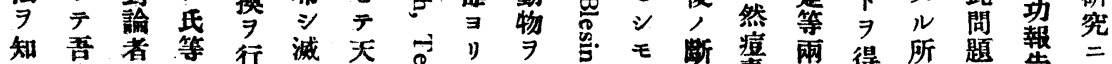

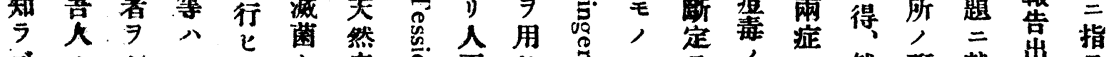

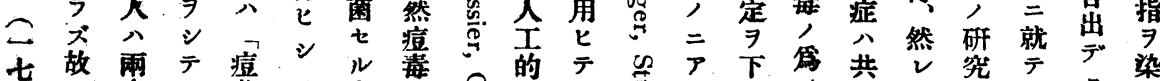

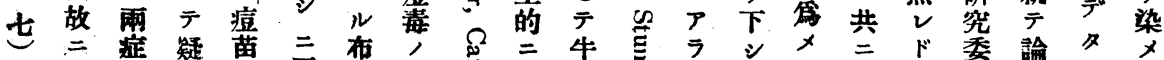

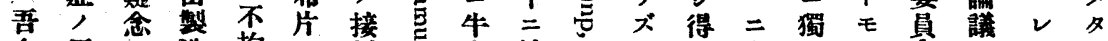

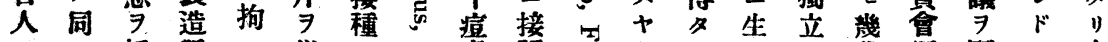

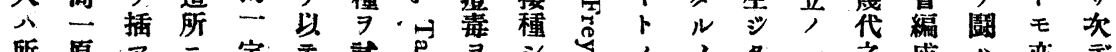

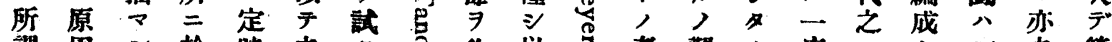

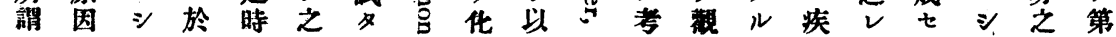




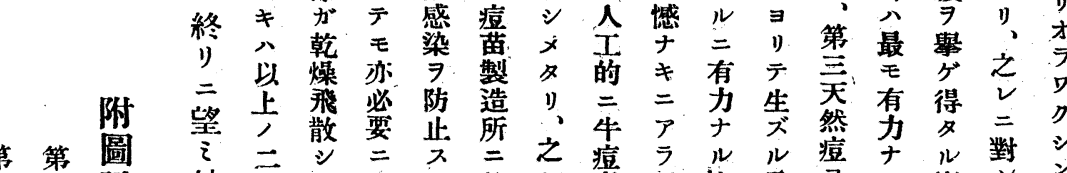

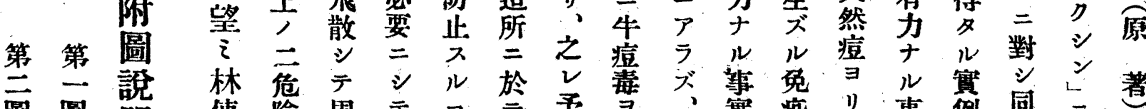

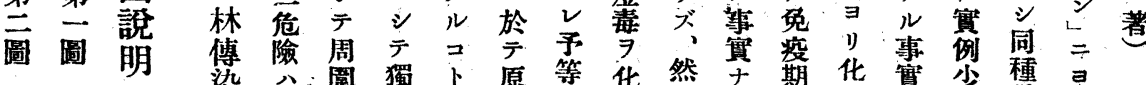

天 天

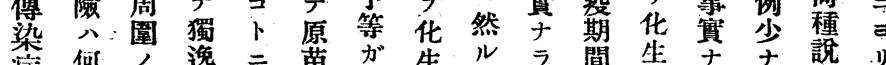

然 然

痘 痘

家 家

兔 兔

装装

丸 丸

第 第

岱 䒫

苗

7 斗

榇簵

サ

2

ル.ル

家

兔 兔

第 第

豆虎萀

背 背

部 部

秡秡

右 右

端 端

千

倍 倍

中 中

央 央

孚倍

票左

倍 端

左 倍

端 稀

五 釋

干

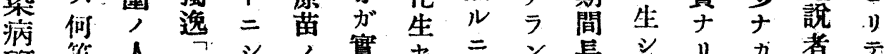

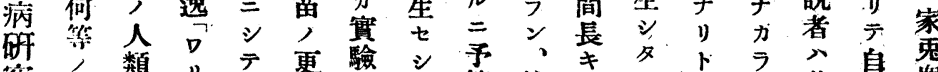
䈵煩類

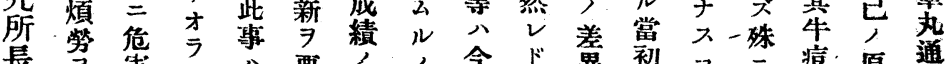

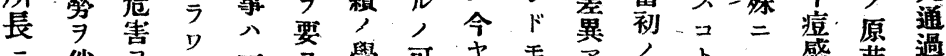
敬华及

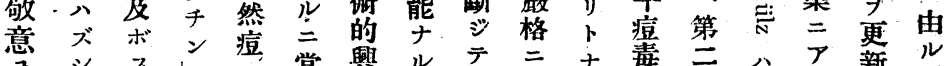

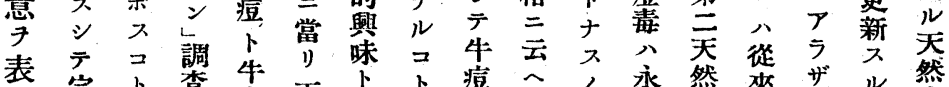

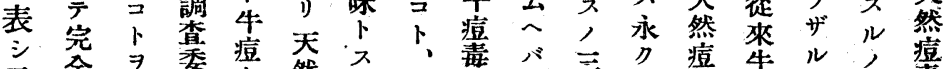

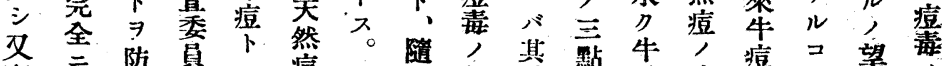

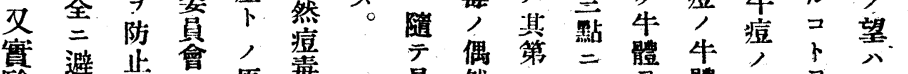

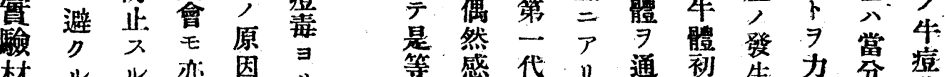

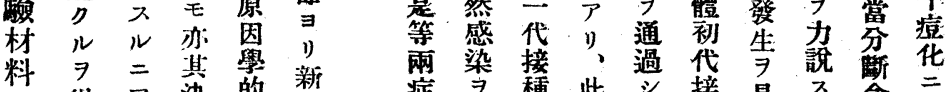

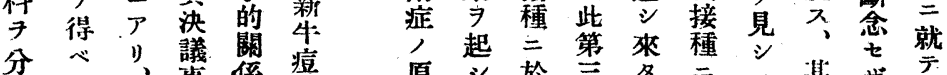

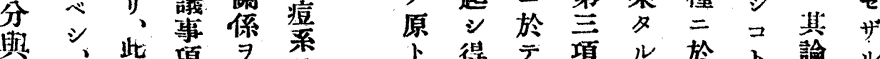

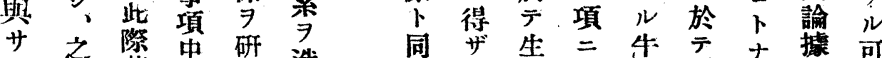

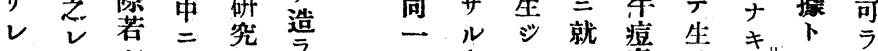
タ此关特 ス

村究痘紫際

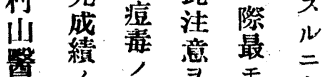
學惯全揭必際 士䨪 向揭蜜

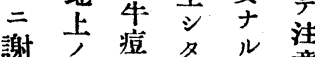

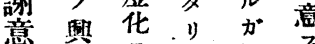
意棟 $入$ 、如

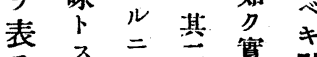
表至至算

家㜪

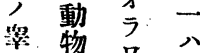

丸品動

内接学物

於野之接

$\overline{\bar{T}}=$ 原種

之殘種野

ᄂ. 留 $\Rightarrow=$

$\exists$ 七製 4

培 ス 痘

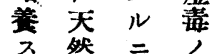

原箱痘異

體織、疮論 $モ$ 痘力八 結 ヨ丙, 者人笣, 第論 1) $=$ 牛少及公內 出於痘于车普地平暗

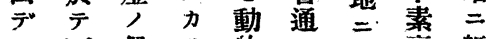
及天偶亏物人於毫既 ル然然ザ二牛冧出 $モ$ 痘感 $v$ 對痘天牛報 㶳染

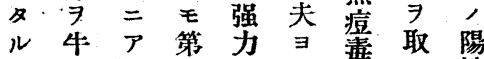

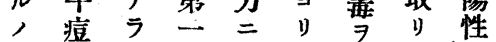

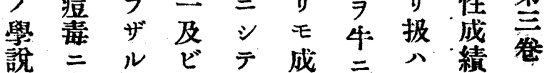
箖 コ第毒然接ザ梦 一ゼ卜三力枆儿以

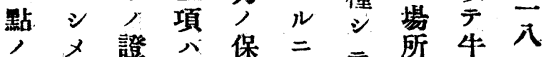
疑得明正存稍宁等

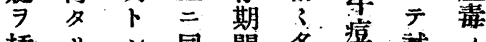

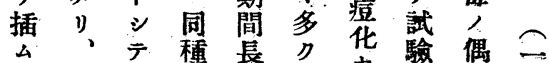

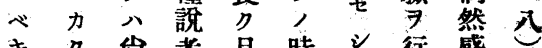
那向者县唗文行感 餘 $\bar{r}$ 木 地天消主 $\ni$ 得以 然極張 $v$ 要 ₹ 痘的 $\exists$, 偒 $尹$ 二妻夕確接ルが性措 


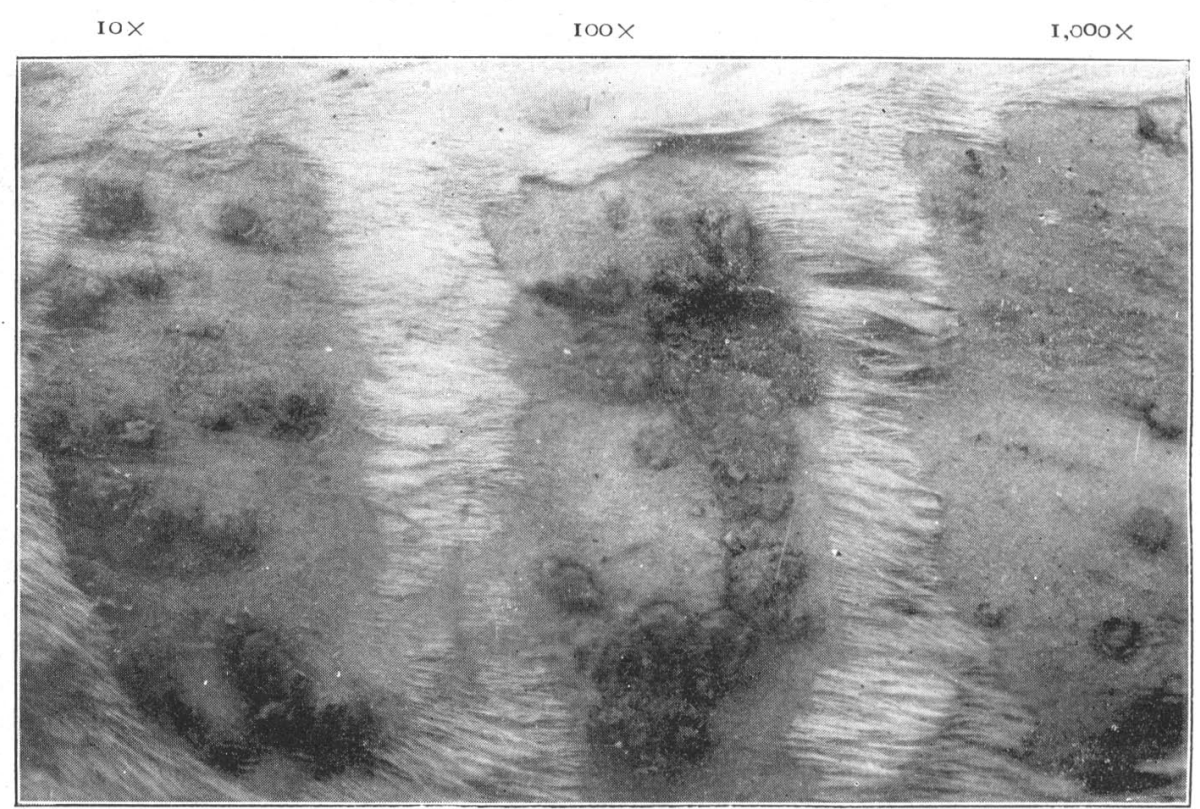

井

論

文

附

圖

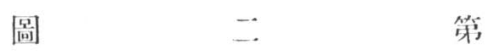

$5,000 \times$

$2,500 \times$

I, $000 \times$

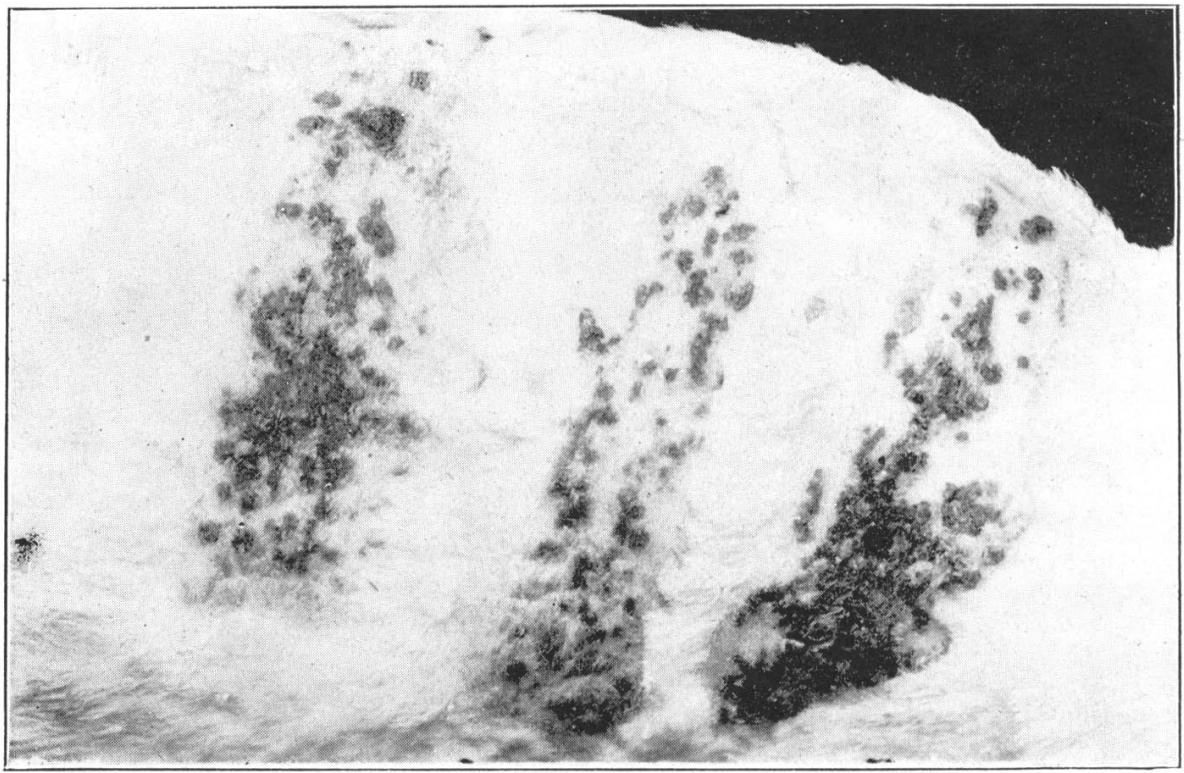




\title{
Etude expérimentale sur la transformation du virus variolique en vaccine par le passage du testicule du lapin.
}

\author{
Par
}

\section{Naoyoshi Kii, Tanesaburo Shimatani et Hisao Kasai.}

(A l'Institut pour maladies infectieuses, de l'Unıversité impériale de Tokyo.)

Les auteurs ont essayé d'expérimenter si le tissu testiculaire du lapin peut permettre de multiplier le virus variolique comme celui de la vaccine et de le transformer en vaccine.

Comme matière d'expérience, les auteưrs ont recueitlì des croûtes sur 6 varioleux. Avec ces croûtes, ils ont préparé 6 émulsions distinctes, diluées Io fois d'eau glycérinée. Ces émulsions ainsi préparées ont été toutes inoculées à la peau de l'abdomen d'un singe pour comparer la virulence des émulsions et choisir la matière d'expérience convenable. $\mathrm{Au}$ bout de quelques jours, des inoculations de l'une des émulsions ont produit des très belles pustules; mais les autres: n'ont produit que des vésicules plus ou moins incomplètes. Les auteurs ont donc pris l'émulsion la plus active pour faire leur expériences.

Des inoculations de cette émulsion ont été pratiquées sur diverses parties du corps d'un lapin: à la cornée (par la scarification), aux muqueuses labiales et nasales (par les scarifications), à la peau rassée du dos (par les frottements de pointe rugueuse d'une pipette chargée d'émulsion), et enfin, en même temps, on a injeté I cc de l'émulsion à l'un des testicules de cet animal.

A la cornée, une légère tuméfaction s'est tout simplement manifestée ; mais elle a bientôt disparu; aux muqueuses et à la peau, on n'a observé aucune altération nosologique; tandis que, au testicule, l'injection a provoqué une inflammation hémorrhagique assez remarquable.

I.'émulsion préparée avec le testicule enflammé a été inoculée de nouvenù à la peau et aux testicules d'un autre lapin. Cette fois, les 
testicules inoculés ont présenté une inflamnation hémorrhagique beaucoup plus intense que celle qui avait été observés pour le lapin précédent; quant à la peau, on n'a observé aucune éruption appréciable.

Mais après 2 passages testiculaires, le virus a pris au premier la force de produire quelques pustules bien nettes sur la peau rasée du lapin inoculé (fig. . I); de plus, le virus arrivé à la $3^{\text {me }}$ génération de la culture testiculaire a relevé subitement sa virulence pour la derme, de telle sorte que même la pulpe testiculaire diluée à i/rooo peut donner les vésicules bien confluents sur la peau rasée du lapin (fig. 2).

En outre, presque en même temps, les auteurs ont pratiqué des inoculations avec les pulpes testiculaires des $\mathrm{I}^{\text {re }}, 2^{\text {me }}$ et $3^{\text {me }}$ générations, à la peau du ventre de quelques génisses; ces inoculations ont été faites par les scarifications à l'aide d'un scarificateur d'Ouméno. Les résultas obtenus ont été parfaitement en accord avec ce qu'on avait observé chez les lapin, cet-à-dire que le virus de la I $^{\text {re }}$ génération n'a donné aucune éruption manifeste; celui de la $2^{\text {me }}$ génération a présenté simplement quelques pustles isolées, et enfin, celui de la $3^{\text {me }}$ génération a produit des pustules bien confluentes à tous les a nimaux inoculés.

Ayant la conviction absolue que le virus variolique est complètement transformé par les passages successifs des testicules du lapin én pure vaccine, les auteurs ont décidé d'oser inoculer à 3 enfants la pulpe prélevée 'sur une génisse qui avait subi l'inoculation de l'émulsion testiculaire du lapin de la $3^{\text {me }}$ génération; les symptômes locaux et généraux que présentèrent les enfants inoculés furent tellement analogues à ceux de cowpox qu'il etait impossible de les distinguer.

Les auteurs ont ainsi réussi à trânsformer le virus variolique en vaccine par le passage des testicules du lapin, en se servant d'un seul lapin comme culture originale; cependant pourrait-on obtenir toujours également les mêmes résultas aussi heureux,. en employant tous les animaux de cette même espèce? Pour connaître l'influence individuelle du lapin concernant la réçeptibilité de testicule pour la variole et la relation de la virulence du virus originaire, les auteurs ont injecté d' abord aux testicules 
droits de 4 lapins la même matière qui avait servi à l'expérience précédente avec succès, et aux testicules gauches de tous ces animaux les émulaions varioliques dont la virulence assez faible etait prouvée sur la peau de singe ; ensuite; au même moment, les inoculations avec l'émulsion de même origine qui avaient été injectées à chaque testicule, ont été pratiquées aussi aux côtés correspondants de la peau dorsale de ces mêmes animaux.

De ces 8 testicules inoculés, un seul qui a reçu le virus, le plus fort, a présenté les signes de l'inflammation (le virus de ce testicule a donné encore, après un passge testiculaire, quelques pustules typiques à des génisses), tandis qué les autres testicules n'etaient pas aptes à cultiver le virus variolique; du reste, sur la peau de tous ces lapins, on n'a observé aucune réaction appréciable.

D'autre part, avec la nouvelle souche variole-vaccinale ainsi obtenue, les auteurs ont exécuté des générations successives de testicule à testicule du lapin; bien que la virulence ait subi des oscillations assez notables jusqu'à la $7^{\text {me }}$ génération, après cela, à chaque génération, elle a augmenté progressivement; enfin, arrivée à la $12^{\text {me }}$ génération, elle a atteint son maximum.

Jusqu'à présent, les auteurs sont parvenus à faire des cultures testiculaires à la $17^{\text {me }}$ génération, sans observer la moindre atténuation de son activité.

Les auteurs peuvent donc dire que c'est un fait bien intéressant de constater que le virus vaccinal provenant du virus variolique transformé au début dans le tesitcule de lapin, arrive si rapidement à son maximum de virulence, tandis que la vaccine, qui passait toujours par les seuls tissus cutanes des bovidés, nécessite au moins une quarantaine de. passages pour s'adapter parfaitement au tissu testiculaire du lapin (observations de Nogouchi et des auteurs de ce travail).

Les auteurs terminent leur exposé en disant que les faits observés ne manquent pas d'un certain intérêt scientifique, puisque, en effet, on a pu transformer le virus variolique en vaccine dans un organe où l'on peut éviter parfaitement l'infection accidentelle vaccinale: c'est un fait des plus 
favorables pour assurer l'opinion de souche commune de la variole et de la vaccine. De plus, au point de vue pratique, quand on utilise ce moyen pour obtenir une nouvelle souche du variolo-vaccin, on pourrait réduire beaucoup les minutieuses précautions nécessaires pour éviter la contamination accidentelle vaccinale à l'écurie et le danger d'éparpiller le virus variolique dans le contour.

(analysé par N. Kii.)

\section{On the Resistance of the Red Blood-Corpuseles to Hypotonic Salt-Solutions in the Infectious. Anemia of Horses.} By

\section{Dr. vet. Masanori Nagao.}

(From the Institute for Infectious Diseases of the Imperial University of Tokyo.)

The author determined the resistance of the red blood-corpuscles against hypotonic solutions of sodium chlorid in $\mathrm{I} 2$ experimentálly infected cases of "infectious anemia of horses." The method employed by the author is in principle similar to that of Hamburger. It only differs from the latter in the point that the mixture of blood-corpuscles and salt solutions remains for one hour in a thermostat and for 20 hours in an icechamber. The results obtained from the author's experiments are as follows:

1) In 30 control horses the maximum- and minimum-resistance of the red blood-corpuscles is on an average as high as $0,45 \mathrm{~g} / \mathrm{dl}$ and 0,54 $\mathrm{g} / \mathrm{dl}$ of salt solution respectively. In $\mathrm{I} 2$ infected horses the author demonstrated a distinct diminution of the resistance, i. e. the maximumand minimum-resistance lies in these cases at $0,5 \mathrm{I} \mathrm{g} / \mathrm{dl}$ and $0,59 \mathrm{~g} / \mathrm{dl}$ respectively. There is, however, in these cases, showing diminished resistance, no distinct relationship between the grade of the anemia (oligocytaemia) and the diminution of the resistance. 